\title{
Voluminous lava flows at Oldoinyo Lengai in 2006: chronology of events and insights into the shallow magmatic system
}

\author{
Matthieu Kervyn • Gerald G. J. Ernst • \\ Jurgis Klaudius • Jörg Keller • François Kervyn • \\ Hannes B. Mattsson • Frederic Belton • \\ Evelyne Mbede $\cdot$ Patric Jacobs
}

Received: 21 February 2007 / Accepted: 28 October 2007 /Published online: 2 February 2008

(C) Springer-Verlag 2007

\begin{abstract}
The largest natrocarbonatite lava flow eruption ever documented at Oldoinyo Lengai, NW Tanzania, occurred from March 25 to April 5, 2006, in two main phases. It was associated with hornito collapse, rapid extrusion of lava covering a third of the crater and
\end{abstract}

Editorial responsibility: P. Delmelle

M. Kervyn $(\bowtie) \cdot$ G. G. J. Ernst • P. Jacobs

Mercator and Ortelius Research Centre for Eruption Dynamics, Department of Geology and Soil Sciences, Ghent University,

Ghent, Belgium

e-mail: Matthieu.KervynDeMeerendre@UGent.be

J. Klaudius $\cdot$ J. Keller

MGI Mineralogisch-Geochemisches Institut,

Albert Ludwigs-University of Freiburg,

Freiburg, Germany

F. Kervyn

Royal Museum for Central Africa, Department of Geology-

Section of Cartography and Photo-Interpretation,

Tervuren, Belgium

H. B. Mattsson

Institute for Mineralogy and Petrology,

Swiss Federal Institute of Technology,

Zurich, Switzerland

H. B. Mattsson

Nordic Volcanological Center, University of Iceland,

Reykjavik, Iceland

F. Belton

Middle Tennessee State University,

Murfreesboro, TN, USA

E. Mbede

Department of Geology, University of Dar es Salaam (UDSM),

Dar Es Salaam, Tanzania emplacement of a 3-km long compound rubbly pahoehoe to blocky aa-like flow on the $\mathrm{W}$ flank. The eruption was followed by rapid enlargement of a pit crater. The erupted natrocarbonatite lava has high silica content $\left(3 \% \mathrm{SiO}_{2}\right)$. The eruption chronology is reconstructed from eyewitness and news media reports and Moderate Resolution Imaging Spectroradiometer (MODIS) satellite data, which provide the most reliable evidence to constrain the eruption's onset and variations in activity. The eruption products were mapped in the field and the total erupted lava volume estimated at $9.2 \pm 3.0 \times 10^{5} \mathrm{~m}^{3}$. The event chronology and field evidence are consistent with vent construct instability causing magma mixing and rapid extrusion from shallow reservoirs. It provides new insights into and highlights the evolution of the shallow magmatic system at this unique natrocarbonatite volcano.

Keywords Oldoinyo Lengai · Hornito collapse · Lava flow Collapse pit · MODLEN

\section{Introduction}

Oldoinyo Lengai (OL), in the East African Rift of NW Tanzania, is the only active terrestrial natrocarbonatite volcano. At the start of April 2006, news of an explosive ash eruption at OL were spread in the Tanzanian and international media (Ihucha 2006a) and reported to the volcanological community (Smithsonian Institution/USGS Weekly Report 2006a). The original reports were contradicted by local observers who reported on a lava flow, exceptionally voluminous by OL standard but without major explosive activity. Critical re-examination and eval- 
uation of observations from eyewitnesses and news reports using complementary remote sensing (RS) data and field observations of the eruption products allow us to propose a chronology for this eruptive event. The goal of this paper is to document this large eruption, to propose a conceptual model accounting for observations and to highlight implications for the structure of the shallow magmatic system.

OL has been regularly erupting natrocarbonatite lava since 1983 (e.g. Keller and Krafft 1990; Dawson et al. 1995). Typical eruptions are characterised by lava fountains and flows of very fluid natrocarbonatite lava (Norton and Pinkerton 1997) at low effusion rates $\left(\sim 0.3 \mathrm{~m}^{3} \mathrm{~s}^{-1}\right)$, producing small lava flows $\left(<100 \mathrm{~m}^{3}\right)$ in the crater. Since late 1998 , lava frequently overflowed the crater rim to flow a few hundred meters down the flanks (GVN 1999). In rare cases, larger natrocarbonatite eruptions occur in association with hornito flank collapse and high effusion rate (GVN $2005 \mathrm{a})$, or with lavas of elevated $\mathrm{SiO}_{2}(\sim 3 \%)$ and crystal content (i.e. 80\%), as in June 1993 (Dawson et al. 1994; 1996; Petibon et al. 1998). From June 14 to June 29, 1993, two lava flows with volumes of $\sim 4.3 \times 10^{4}$ and $\sim 10.4 \times$ $10^{4} \mathrm{~m}^{3}$, respectively, were emitted over $\sim 14$ days, in association with an explosive eruption, which formed several asymmetrical ash cones (Church and Jones 1994; Dawson et al. 1994).

Since 1883 , OL has had several mixed silicate-natrocarbonatite explosive eruptions, the last ones being in 19661967 (Dawson et al. 1992, 1995; Dawson 1998). These produced ash plumes up to $10 \mathrm{~km}$ elevation a.s.l. (Dawson et al. 1995) affecting the local Masai, cattle and wildlife (i.e. highly alkaline ash polluting water sources and causing skin rashes). These explosive eruptions also affected airports within $200 \mathrm{~km}$ of OL.

This paper is structured as follows: first, reports from visits to OL shortly before, during or just after the MarchApril 2006 eruptions are summarised and compared with news media information; second, Moderate Resolution Imaging Spectroradiometer (MODIS) night-time observations are analysed to constrain event chronology; third, field observations collected 2 months after the eruptions (May $21-28,2006)$ are reported to constrain eruption processes; and finally, factors leading to the eruption events and implications for the structure of the shallow magmatic system are discussed. A rheological study for the MarchApril 2006 lava flow is presented in a complementary paper (Mattsson and Hode Vuorinen 2008).

\section{Accounts of the March-April eruption: field and news reports}

Since 2001, activity has been localised in the central part of the crater where a hornito cluster formed by multiple phases of lava spattering and effusion (T56B, T57B, T58B, and T58C, see Fig. 1; GVN 2005b). Inter-related activity at the central hornitos and "gurgling" noise of underground magma movement provided evidence for shallow, interconnected lava reservoirs, immediately underneath hornitos' bases. OL displayed its usual low-level natrocarbonatite activity until mid-March 2006, except for a few higher eruption rate events in July 2004 and 2005 (Table 1). During these, partial hornito collapses (i.e. T58B and T58C, Fig. 1) breached shallow reservoirs causing rapid lava outbursts (Table 1). A 10- to 12-m-wide pit crater formed at T58B in July 2004, occupied by a lava lake or active vents since then. The March-April 2006 eruption was neither preceded by a hiatus in eruptive activity nor by any major change in eruptive style or intensity.

The first eruption reports appeared in the Tanzanian and international media, including CNN, on March 30 (Table 1), citing inhabitants from Engare Sero, the closest sizeable village $(\sim 1,000$ inhabitants) near $\mathrm{OL}, 17 \mathrm{~km} \mathrm{~N}$ of the summit. These news articles described an eruption with loud explosions, ash cloud rise and lava emissions and reported the evacuation of several villages, some more than $40 \mathrm{~km}$ away (GVN 2006). These reports were transmitted via the Global Volcanism Network of the Smithsonian Institution (www.volcano.si.edu) to the volcanology community (Smithsonian Institution/USGS Weekly Report 2006a). A week later, new reports indicated that the eruption had not been explosive; no ash plume had been generated but an unusually large-volume lava flow extended down the $\mathrm{W}$ flank accompanied by a white steam plume produced by lava-ignited burning vegetation (Table 1; Fig. 2a; Kafumu et al. 2006; Mbede 2006; Smithsonian Institution/USGS Weekly Report 2006b). The W flank flow stopped about $1 \mathrm{~km}$ before reaching a small family settlement (a so-called Masai "Boma"; Fig. 2b). Except for that Masai family, nobody had actually been evacuated.

The eruption was characterised by two large effusive events, which probably occurred at night (according to Mbede 2006; see hereafter). The event dates are not well constrained by observers. The first eruption phase, which was over by April 1, formed a $\sim 15$-m-wide, near-cylindrical pit affecting hornitos T56B and T58B (Figs. 1 and 3). A canyon from a breach in the $\mathrm{S}$ flank of the then stillstanding T58C fed a lava flow. The flow filled up the S part of the crater, flowed over the $\mathrm{W}$ crater rim and down the flank. Regional authorities visited OL on April 1 and 7 to assess the situation (Table 1). They forbade access to the volcano, but no enforcement actions were taken. Tourists continued visiting OL.

University of Dar es Salaam geologists visited Engare Sero, on April 8; climbed OL on April 9. From discussions 
Fig. 1 Map of OL active crater as observed on May 25, 2006, based on a GPS survey (Garmin Etrex Vista). Inset Sketch map from a similar survey in February 2006 (courtesy of C Weber). Collapse of the crater central part destroyed three of the largest hornitos. T37 collapsed in June 2006 and T49B partially collapsed by end 2006

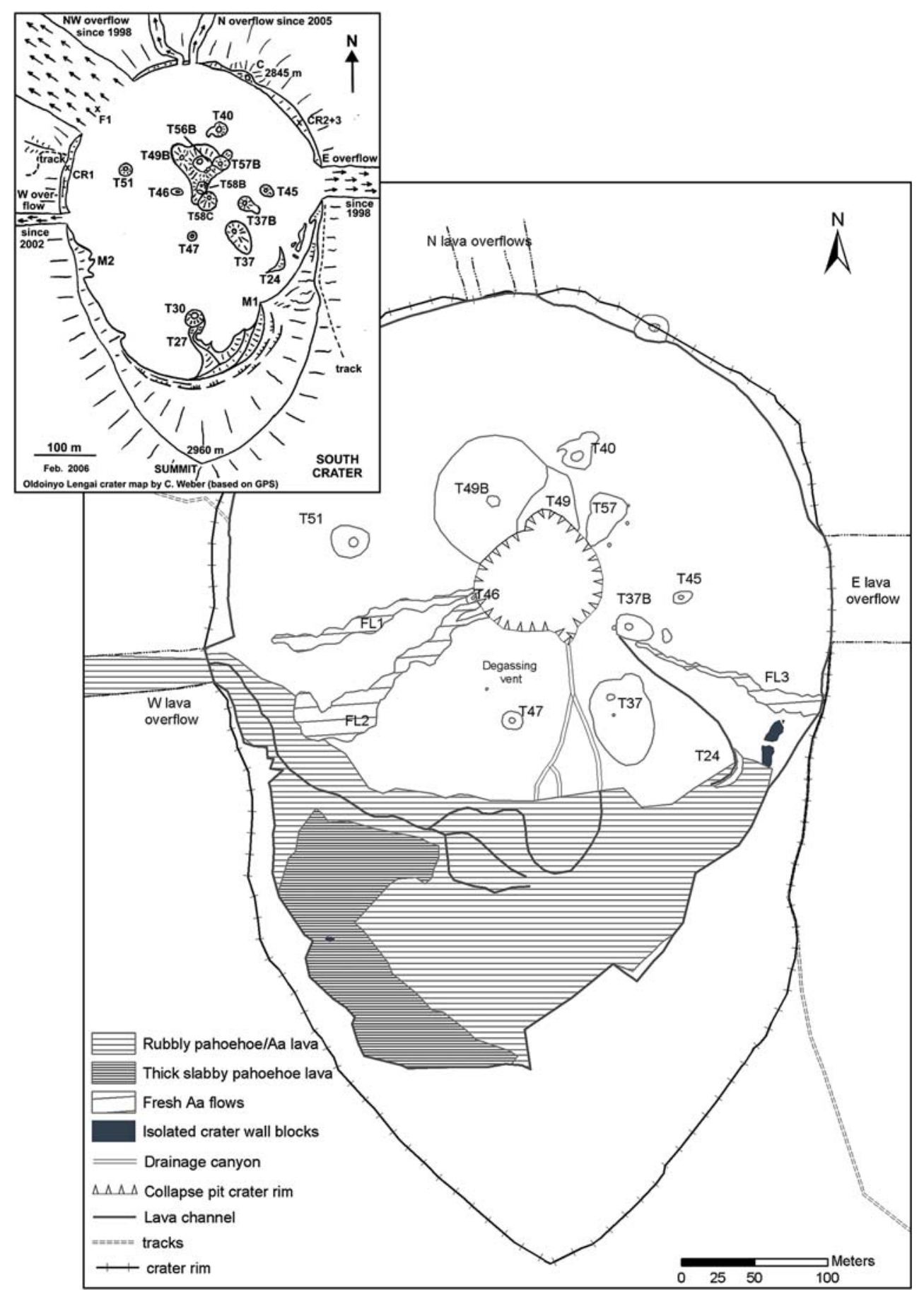

with village authorities, they reported the main eruption started, with tremors and explosion noises, at $\sim 4$ A.M. on March 25, i.e. 5-6 days earlier than indicated in other reports (Mbede 2006). Lava was seen shortly thereafter to overflow the crater rim and to extend onto the $\mathrm{W}$ flank. Villagers said this first phase ended on April 1; a second phase occurred between April 2 and April 5 again on W flank. There were periods of lava fountaining at source, but little ash was produced.

\section{Thermal RS observations}

Before the March-April 2006 eruptions, thermal RS monitoring of OL was developed at UGhent based on daily night-time MODIS satellite data, building up from thermal RS observations at OL by Oppenheimer (1997). MODLEN, an adaptation of the MODVOLC algorithm (Wright et al. 2004), is designed to detect low intensity thermal anomalies at OL, based on threshold values applied to a Normalised 
Table 1 Summary table of observations from eyewitnesses, of reports in the news media and of actions taken by authorities before, during and directly after the March-April 2006 eruption

\begin{tabular}{|c|c|c|}
\hline Dates & Observations-accounts & Source/reference \\
\hline 2001-March 2006 & $\begin{array}{l}\text { Eruptive activity focuses in central part of summit crater; hornito cluster forms by multiple } \\
\text { phases of lava spattering and effusion. Activity provides evidence for shallow lava pools, } \\
\text { located immediately underneath the base of single hornitos }\end{array}$ & $\begin{array}{l}\text { GVN 2002, 2003, 2004; } \\
\text { Fig. } 1\end{array}$ \\
\hline 07-15-2004 & $\begin{array}{l}\text { Intense eruption phase from T58B and } \mathrm{C} \text { with ash jets, } 10-\mathrm{m} \text { high lava fountains. Breaching of } \\
\text { T58B hornito's flank causes flooding of the central-eastern crater floor by voluminous lava at } \\
\text { estimated peak flow rate } \sim 10 \mathrm{~m}^{3} \mathrm{~s}^{-1} \text {. Formation of } 10-12 \mathrm{~m} \text { wide pit crater at central hornito } \\
\text { T58B. Interactions between eruptive activities at different central hornitos: activity stopping at one } \\
\text { vent when new vent opened nearby }\end{array}$ & F. Belton; GVN 2005a \\
\hline 07-04-2005 & $\begin{array}{l}\text { Interactions between eruptive activities at different central hornitos with several neighbouring } \\
\text { vents active simultaneously }\end{array}$ & GVN 2005b \\
\hline $07-21 / 22-2005$ & Lava fountain and voluminous flows produced at high rate $\left(0.5 \mathrm{~m}^{3} \mathrm{~s}^{-1}\right)$ from T58C & F. Belton; GVN 2005b \\
\hline 08-04-2005 & Lava lake in T58B pit crater & C. Weber; GVN 2005b \\
\hline 02-07-2006 & Four vents active in T58B pit crater. Low level eruptive activity from central vents & C. Weber \\
\hline 03-13-2006 & $\begin{array}{l}\text { Last photograph of crater before March } 25-\text { April } 5 \text { eruptions shows some fresh, } \\
\text { small-volume natrocarbonatite flows, some reaching NW and E crater rims }\end{array}$ & $\begin{array}{l}\text { R. Rosen; Airplane } \\
\text { picture, Fig. 3a }\end{array}$ \\
\hline 03-25-2006 & $\begin{array}{l}\text { Start of main eruption phase in early morning with tremors, explosion sounds. Lava, promptly } \\
\text { afterwards, overflows crater rim and extends onto W flank. Lava fountaining at source }\end{array}$ & Mbede 2006 \\
\hline $03-27 / 30-2006$ & White plume rising from summit, mistakenly reported as ash plume in news reports & Mbede 2006 \\
\hline 03-30-2006 & Pilot report seeing lava fountains and a large lava flow moving down flank, without ash emission & M. Dalton-Smith \\
\hline 04-01-2006 & $\begin{array}{l}\text { Deep, } \sim 15 \mathrm{~m} \text { wide pit crater formed by partial collapse of T58B/T56B. 1-m-wide deeply incised } \\
\text { canyon from } \mathrm{S} \text { base of still standing T58C. Lava from canyon filled up low-lying areas of } \\
\mathrm{S} \text { part of crater, then flowed over } \mathrm{W} \text { crater rim and down } \mathrm{W} \text { flank }\end{array}$ & $\begin{array}{l}\text { D. Polley; Airplane } \\
\text { picture, Fig. } 3 \mathrm{~b}\end{array}$ \\
\hline 04-01-2006 & $\begin{array}{l}\text { "Hundreds of villagers living around Oldoinyo Lengai (...) have been forced to flee their homes } \\
\text { after the volcano erupted on Thursday [March 30]. Eyewitnesses said they heard a rumbling } \\
\text { noise before the volcano began discharging ash and lava, prompting local residents to flee the } \\
\text { area in their hundreds. District officials estimated that about 3,000 people from Nayobi, } \\
\text { Magadini, Engaruka, Malambo, Ngaresero, Gelai Bomba and Kitumbeine villages left their } \\
\text { homes within a few hours of the eruption (...). (...) smoke was seen coming from the peak } \\
\text { of the mountain, (...) people panicked after lava began pouring out of the volcano. (...) The } \\
\text { eruption destroyed vegetation and polluted water sources, but no casualties were reported" }\end{array}$ & $\begin{array}{l}\text { The Guardian } \\
\text { (Ihucha 2006a) }\end{array}$ \\
\hline 04-01-2006 & $\begin{array}{l}\text { W flank flow reached maximum length. No activity in crater; near-circular pit crater emitting } \\
\text { water vapour and other gases (i.e. with a weak sulphur smell) }\end{array}$ & M. Jones \\
\hline 04-01-2006 & Ngorongoro District Commissioner climbs OL to assess the situation & Kafumu et al. 2006 \\
\hline 04-04-2006 & $\begin{array}{l}\text { Pilot report seeing from distance short-duration but very high lava fountain issuing from new } \\
\text { collapse pit. Lava lake occupying pit crater. Flow on W flank glowing }\end{array}$ & M. Dalton-Smith \\
\hline 04-07/08-2006 & $\begin{array}{l}\text { Arusha Regional Commissioner visits OL summit. Lava lake still active within collapsed pit } \\
\text { crater but not sourcing lava overflow to } \mathrm{W} \text { flank any longer. Pit crater estimated at } \sim 30 \mathrm{~m} \\
\text { across from } \mathrm{N} \text { to } \mathrm{S} \text { and at } \sim 15 \mathrm{~m} \text { across from } \mathrm{E} \text { to } \mathrm{W}\end{array}$ & $\begin{array}{l}\text { A. Bupunga- } \\
\text { Tanzannature Safari }\end{array}$ \\
\hline 04-09-2006 & $\begin{array}{l}\text { Flow on } \mathrm{W} \text { flank still steaming in several distal places. Lava lake in pit crater actively } \\
\text { degassing. T58C still partially standing at edge of collapsed area }\end{array}$ & Mbede 2006 \\
\hline 04-15-2006 & $\begin{array}{l}\text { Ngorongoro Conservation Area Authorities issues travel advisory, warning local tour operators } \\
\text { not to take tourists near OL. OL access forbidden for April (concerns that further volcanic } \\
\text { eruptions could occur) }\end{array}$ & Ihucha $2006 \mathrm{~b}$ \\
\hline 04-17-2006 & $\begin{array}{l}\text { "There was an exodus after the volcanic mountain rumbled into red-hot landslide, spewing } \\
\text { scalding fumes and lava all over the neighbourhood" }\end{array}$ & $\begin{array}{l}\text { The Guardian } \\
\text { (Mvungi 2006) }\end{array}$ \\
\hline 06-20-2006 & $\begin{array}{l}\text { Recent major flow in SE part of crater on July 13,2006, corresponding to a major MODIS } \\
\text { thermal anomaly on June } 20,2006\end{array}$ & $\begin{array}{l}\text { S. Beresford } \\
(07-13-2006)\end{array}$ \\
\hline 06-18-2007 & $\begin{array}{l}\text { New natrocarbonatite activity in crater with three active lava lakes, four new spattering hornitos } \\
\text { and flows inside pit crater }\end{array}$ & H. Mattsson \\
\hline
\end{tabular}

Most of these observations were compiled on an OL dedicated website by one of the authors (http://www.mtsu.edu/ fbelton/lengai.html) 
Fig. 2 a White degassing plume above OL seen from $\mathrm{N}$ on March 30, 2006. b Lava flow, with aa-like surface texture, on the lower W flank photographed on April 9, 2006. Lava flow exits a deep gully to form a wider lobe on the lower flank shallower slopes. When photographed, the lava had stopped for at least 5 days but was still hot in places. White degassing plumes can be observed within the cooling flow. Some low viscosity lavas with pahoehoe surface texture, extruding from the well-marked lava front, had continued flowing along small gullies for several hundred metres. Lava flow reaches to within $1 \mathrm{~km}$ of closest Masai boma
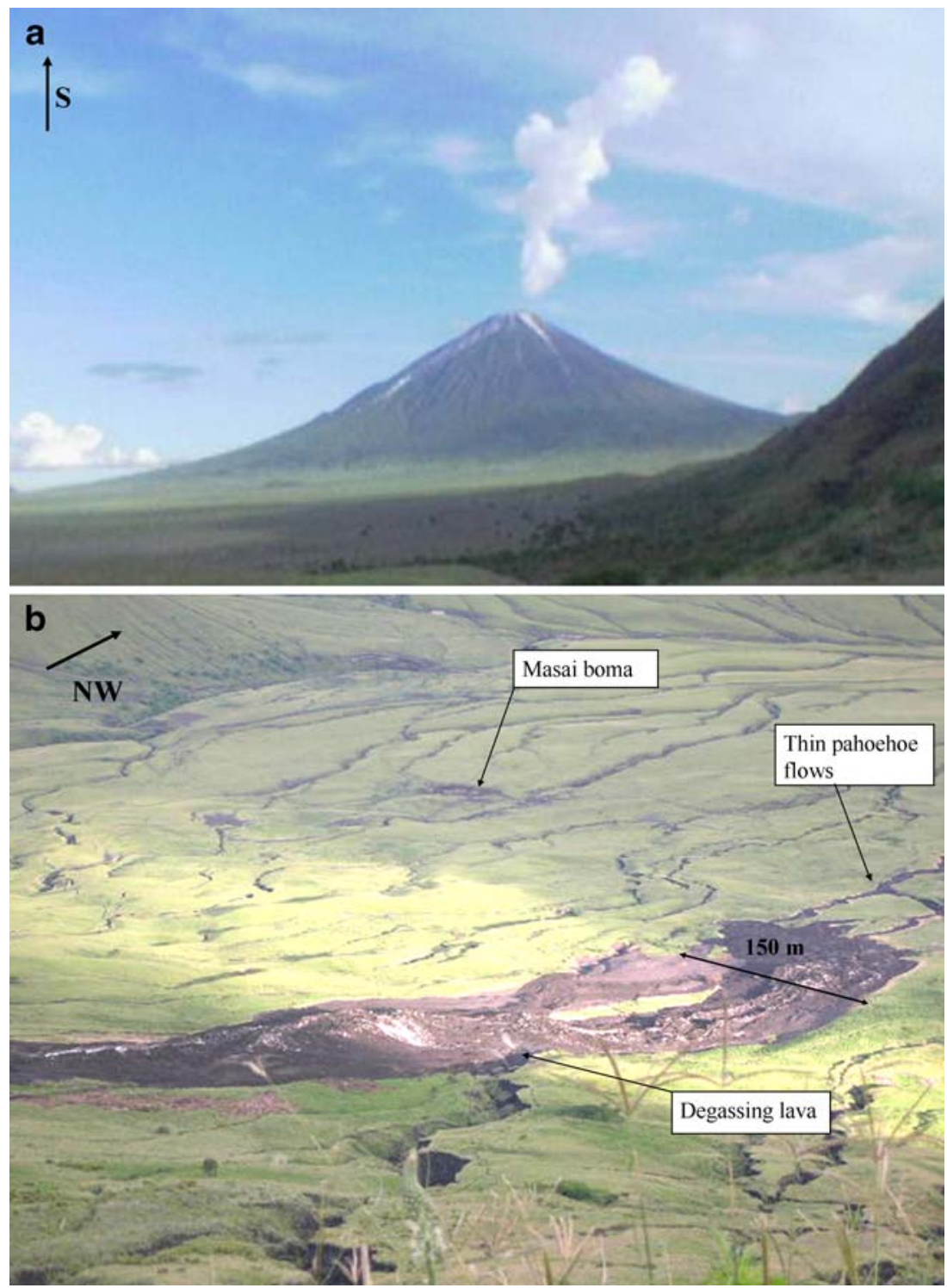

Thermal Index (NTI, Kervyn et al. 2008). MODIS data analysis for March-April 2006 helped constrain the onset, duration and end of the eruption and relative activity level changes although the volcano was often covered by clouds, as is common during the local rainy season, which lasts from February to May. Daytime MODIS images were visually inspected to further constrain observations. MODIS observations are illustrated in Fig. 4 and summarised in Table 2. Key points are highlighted hereafter.

Short-duration (i.e. no repeated anomalies in successive scenes) and low-intensity anomalies were detected on March 11, 13 and 18, suggesting lava flow eruptions of an ordinary size for OL i.e. $\leq 10^{2} \mathrm{~m}^{3}$. These anomalies match observations of multiple fresh flows extending to the NW and E crater rim from the central hornito cluster (Table 1; Fig. 3a). The first main thermal anomalies were recorded at night on March 22 and 23, despite cloud coverage (Table 2; Fig. 4a). It suggests emplacement of voluminous flows in the $\mathrm{E}$ part of the crater, anomalies appearing on the upper $\mathrm{E}$ flank probably being related to slight inaccuracy in scene georeferencing.

March 25 marked the first eruption peak, with first intense anomalies being detected close to the summit on the daytime TERRA image (i.e. acquired at 11:00 A.M. local time). In the night of March 25-26, anomalies covered an extensive part of the W flank (Fig. 4; Table 2). Anomalies were detected as far as $\sim 2.8 \mathrm{~km}$ from the crater with the highest anomalies at mid-flank. These data indicate that lava overflowed the crater rim and extended down the $\mathrm{W}$ flank on March 25 and that it had already reached its full length by 11:20 P.M. This fits with local Masai accounts of the first phase starting at 4:00 A.M. on March 25.

During March 27, intense anomalies were recorded at the crater indicating an active lava lake within a collapse pit 

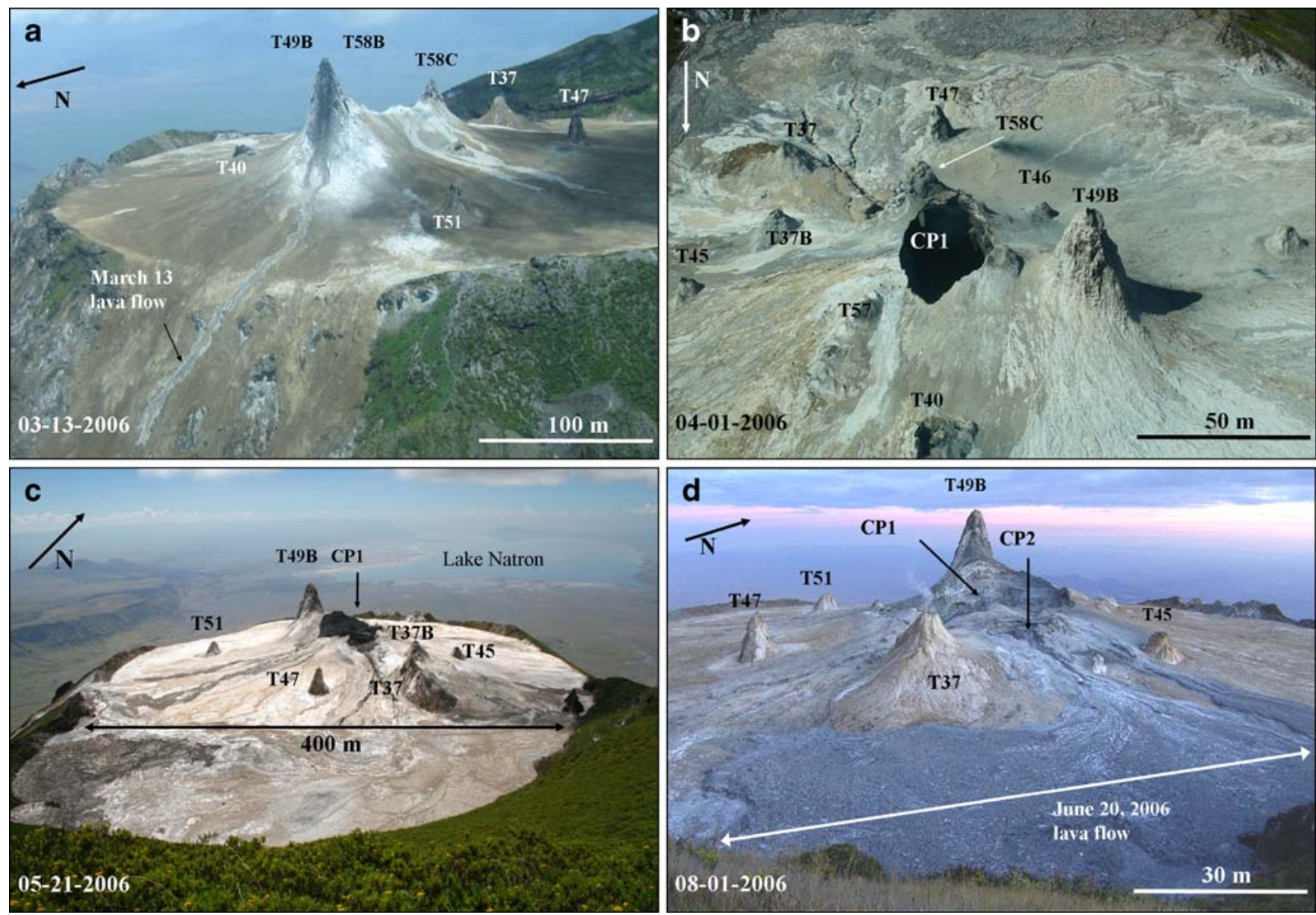

Fig. 3 a OL crater looking ESE; viewed from a plane on March 13, 2006, before two central hornitos collapsed on March 25 (courtesy of R. Rosen). A fresh flow from T49B overflows NW crater rim. b Central part of crater showing the collapse pit $(C P 1)$; imaged from a plane on April 1, 2006 (courtesy of D. Polley), in between the two

crater and possible additional lava emplacement within the $\mathrm{S}$ part of the crater. Lower intensity anomalies on the $\mathrm{W}$ flank can be ascribed to cooling of the March 25 flow. On March 29, low-intensity anomalies were detected within the crater indicating waning activity, restricted to the crater. The last anomaly for the first eruption phase was in the afternoon of March 30 (Table 2). Absence of anomaly over the next 3 days (March 31-April 2) suggests that no voluminous lava was emitted then. The emplaced lava surface had already cooled down to below detection limit (note that natrocarbonatite lava cools to half its initial temperature in only $\sim 1 \mathrm{~h}$, Pinkerton et al. 1995).

The second main activity phase and lava overflow on the W flank occurred early on April 3. A spatially extensive anomaly (i.e. 6 pixels) was detected on the $\mathrm{W}$ flank for two daytime MODIS scenes (Table 2). This anomaly was more intense and extensive onto the lower flanks on night-time scenes, reaching down $3 \mathrm{~km}$. The last anomalies were visible on the lower W flank on the April 4 daytime AQUA scene (Table 2). From April 5 to 11, dense cloud coverage

eruption phases. $\mathbf{c}$ Crater view from the summit on May 21, 2006. The $\mathrm{S}$ third of the crater is covered by the March-April lava flow. $\mathbf{d}$ Crater view from SE on August 1, 2006; the June 20 flow, issuing from a second pit crater $(C P 2)$ formed by $\mathrm{T} 37 \mathrm{~B}$ collapse (courtesy of D. Szczepanski)

prevented identification of the end of activity. From April 12 , the MODIS scene did not record any additional activity, suggesting that the lava lake formed in the collapse pit crater, still active on April 9, must have cooled or drained.

MODIS data constrain two main effusion pulses. The temporal and spatial evolutions show that the two eruption peaks, which emplaced lava on the $\mathrm{W}$ flank, were of short duration (5-20 h) and occurred on March 25 and April 3.

\section{Field observations}

Detailed mapping and observations were made at the $\mathrm{W}$ flank flow front and within the crater in the last week of May (Figs. 1, 3c and 5). In this period and earlier in May, no eruptive activity was witnessed. There were no signs that activity resumed after April 9. Fumarolic degassing along fissures cutting through the crater rim and from most hornitos (i.e. T37, T37B, T45, T49B and T51) was continuously observed. Rumbling noises, associated with 
Fig. 4 a-e Stretched greyscaled, night-time, MODIS band $22(3.95 \mu \mathrm{m})$ image over OL (identified by the white arrow) acquired by TERRA or AQUA platforms. Bright pixels $\left(\sim 1 \times 1 \mathrm{~km}^{2}\right)$ at or close to summit indicate presence of hot lava. $\mathrm{N}$ is up in each image. Interpretations of the thermal anomalies given in Table 2 . f Generalized sketch of topographic features visible on MODIS scenes: Crater Highlands to SW $(\mathrm{CrH})$, including Embagai caldera lake; Lake Natron to $\mathrm{N}(L N)$; Gelai $(G)$ and Ketumbeine $(K)$ shield volcanoes; Oldoinyo Lengai $(O L)$ and Kerimasi strato-volcanoes $(K r)$; rift valley wall denoted by stippled line. Image contrast has been stretched independently for each scene to optimize visualisation. Scenes $\mathbf{a}, \mathbf{b}$ and $\mathbf{e}$ are affected by clouds. $\mathbf{g}$ Time series of Normalized Thermal Index (NTI) values for the crater, extracted from MODIS nighttime images using the MODLEN algorithm (see Kervyn et al. 2008 for detail), including all MODLEN alerts within $2 \mathrm{~km}$ of the summit from March 6 to April 21. NTI values above $(-0.88$; stippled line $)$ denote eruptive activity in progress within the crater whereas NTI values below $(-0.92$; hatched area) are characteristic for dense cloud coverage masking the summit. Data acquisition gaps are marked by grey vertical bars. Data were acquired for the night between the plotted date and following day. Numbers refer to interpretation of key features in Table 2
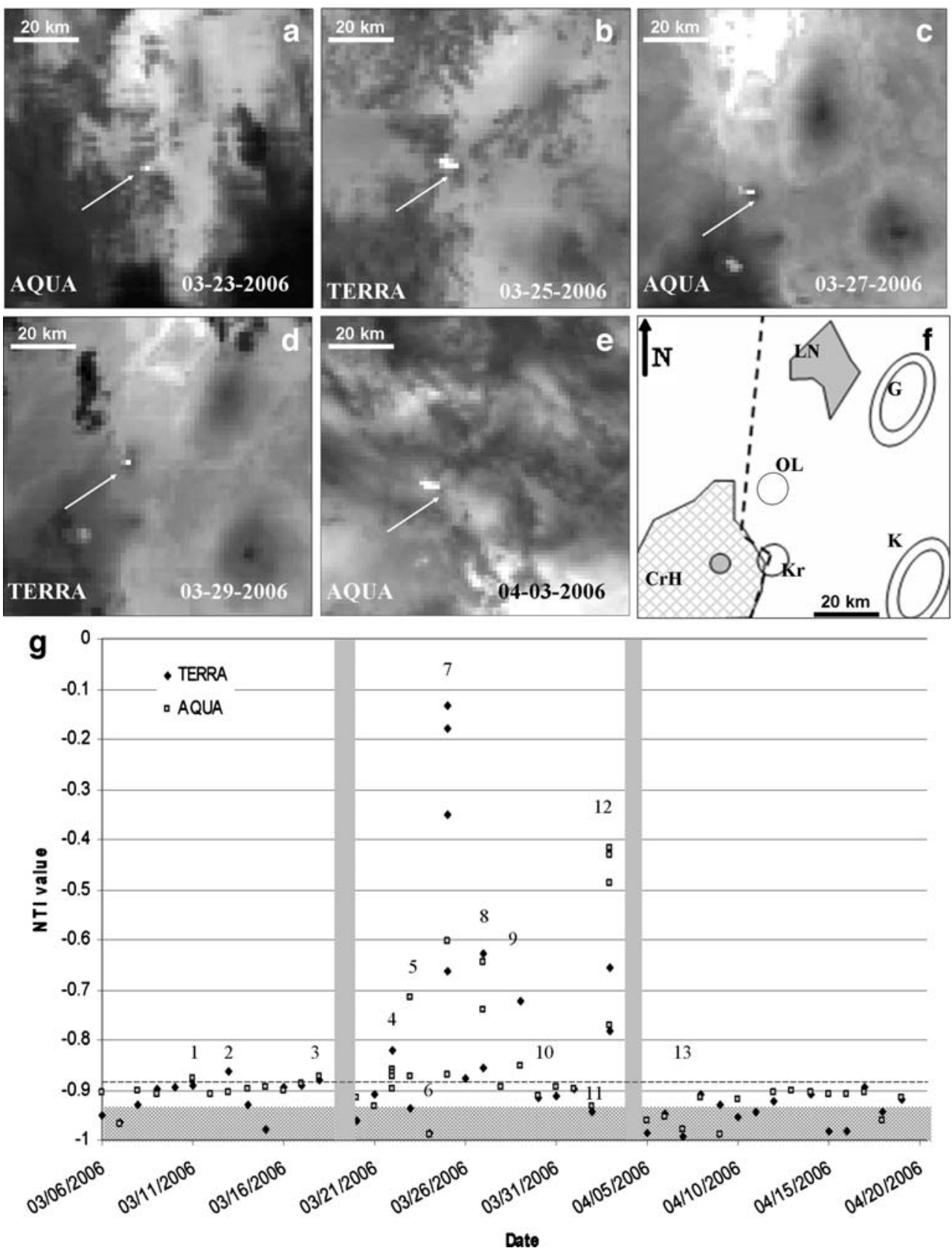

ground movements, lasting for a few seconds were heard several times per hour and felt in the crater. These noises can be related to ongoing roof collapse within sub-surface cavities (i.e. drained shallow reservoirs) underneath the central hornito cluster. In the following sections, observations made in the crater and on the $\mathrm{W}$ flank are described.

\section{A new collapse pit}

The morphology of the central part of the crater drastically changed compared to February 2006 (Fig. 1). By end of May 2006, the collapse pit (CP1; Figs. 1 and 3c), formed at the central hornito cluster, had caused collapse of T56B,
T58B and T58C, with only their lower flanks remaining around the CP crater rim. On May $27, \mathrm{CP} 1$ was $\sim 85 \mathrm{~m}$ across from $\mathrm{N}$ to $\mathrm{S}$ and $\sim 75 \mathrm{~m}$ across from $\mathrm{E}$ to $\mathrm{W}$. The $\mathrm{CP}$ rim was $\sim 20 \mathrm{~m}$ higher than the visible pit bottom, which was filled up by altered lava scree. T49B, a $60 \mathrm{~m}$-high hornito, to the NW pit margin, was still standing but $\mathrm{CP}$ was undercutting its SE flank. Figures $4 \mathrm{~b}-\mathrm{c}$ and 6 show that CP1 enlarged rapidly after the March 25-April 5 eruption.

Cavities were observed in the CP1 walls, where the CP walls cut through hornito flanks. Two cavities at shallow depth, 3-5 $\mathrm{m}$ across, are observed at T46, one within the hornito construct and the second one $2 \mathrm{~m}$ beneath it (Fig. 5a). Similar structures are exposed in the $\mathrm{CP}$ wall 
Table 2 Summary of observations and interpretation of MODIS thermal data

\begin{tabular}{|c|c|c|c|c|c|}
\hline $\begin{array}{l}\text { Fig. } \\
4 \\
\text { nos. }\end{array}$ & 2006 Dates & $\begin{array}{l}\text { Number of thermally } \\
\text { anomalous pixels }\end{array}$ & $\begin{array}{l}\text { Scene } \\
\text { type }\end{array}$ & $\begin{array}{l}\text { Level and localisation } \\
\text { of thermal signal }\end{array}$ & Interpretations/comments \\
\hline \multirow[t]{2}{*}{$\begin{array}{c}1 \text { to } \\
3\end{array}$} & $\begin{array}{l}\text { March } 11, \\
13 \text { and } 18\end{array}$ & \multirow[t]{2}{*}{1 to 2 pixels } & $\mathrm{V}$ & Weak anomaly at summit crater & $\begin{array}{l}\text { Spattering and small-scale flow emplacement mostly } \\
\text { crater-confined }\end{array}$ \\
\hline & $\begin{array}{l}\text { March 19- } \\
21\end{array}$ & & $\mathrm{~V}$ & No data or data affected by clouds & No information \\
\hline 4 & March 22 & $\begin{array}{l}\text { Terra: } 1 \text { pixel } \\
\text { (10:45 P.M.) } \\
\text { Aqua: } 3 \text { pixels }\end{array}$ & $\mathrm{V}$ & $\begin{array}{l}\text { Moderately intense anomalies at, \& } \\
\text { directly } \mathrm{E} \text { of summit }\end{array}$ & Emplacement of thick flows in crater \\
\hline 5 & March 23 & Aqua: 2 pixels & $\mathrm{V}$ & $\begin{array}{l}\text { Minor anomaly at summit and strong } \\
\text { anomaly to } \mathrm{E} \text { of it }\end{array}$ & Emplacement of thick flows in crater \\
\hline \multirow[t]{2}{*}{6} & March 24 & & $\mathrm{~V}$ & $\begin{array}{l}\text { No thermal anomaly; dense cloud } \\
\text { coverage }\end{array}$ & No evidence of thermal activity \\
\hline & March 25 & $\begin{array}{l}\text { Terra: } 4 \text { pix. } \\
\text { (11.00 A.M.) }\end{array}$ & $\mathrm{X}$ & $\begin{array}{l}\text { High intensity, spatially-extensive } \\
\text { thermal anomaly in or close to } \\
\text { summit }\end{array}$ & $\begin{array}{l}\text { Start of first eruption phase; first series of major } \\
\text { hornito collapses; lava flood in crater }\end{array}$ \\
\hline \multirow[t]{3}{*}{7} & March 25 & $\begin{array}{l}\text { Terra: } 11 \text { pix. } \\
\text { (11:20 P.M.) } \\
\text { Aqua: } 6 \text { pix. } \\
\text { (2:15 A.M.) }\end{array}$ & $\mathrm{V}$ & $\begin{array}{l}\text { Multiple intense anomalies at summit } \\
\text { \& on W flank }\end{array}$ & $\begin{array}{l}\text { First eruption peak: summit crater overflow; } 3 \mathrm{~km} \\
\text { long flow down } \mathrm{W} \text { flank }\end{array}$ \\
\hline & March 26 & $\begin{array}{l}\text { Aqua: } 2 \text { pix. } \\
\text { (2:35 P.M.) }\end{array}$ & $\mathrm{X}$ & Moderate anomalies at summit & Active lava lake in $\mathrm{CP}$ crater \\
\hline & & & $\mathrm{V}$ & No anomaly; dense cloud coverage & Unfavourable geometry of acquired scene \\
\hline 8 & March 27 & $\begin{array}{l}\text { Terra: } 4 \text { pix. } \\
\text { (10:45 A.M.) } \\
\text { Terra: } 2 \text { pix. } \\
\text { (11:05 P.M.) } \\
\text { Aqua: } 5 \text { pix. } \\
\text { (2:00 A.M.) }\end{array}$ & $\mathrm{V}$ & $\begin{array}{l}\text { Intense anomaly at summit \& multiple } \\
\text { weak anomalies on } \mathrm{W} \text { flank }\end{array}$ & $\begin{array}{l}\text { Active lava lake in } \mathrm{CP} \text { crater; possible emplacement } \\
\text { of new lava in crater; lava cooling on W flank }\end{array}$ \\
\hline \multirow[t]{2}{*}{9} & March 29 & $\begin{array}{l}\text { Terra: } 2 \text { pix. } \\
\text { (10:55 P.M.) } \\
\text { Aqua: } 3 \text { pix. } \\
\text { (1:50 A.M.) }\end{array}$ & $\mathrm{V}$ & Moderately intense anomaly at summit & Waning, crater-restricted activity \\
\hline & March 30 & $\begin{array}{l}\text { Aqua: } 2 \text { pix. } \\
\text { (2:10 A.M.) }\end{array}$ & $\mathrm{X}$ & Moderately intense anomaly at summit & Last thermal anomaly of first eruption phase \\
\hline 10 & $\begin{array}{l}\text { March } 30- \\
\text { April } 1\end{array}$ & & $\mathrm{~V}$ & No thermal anomaly & $\begin{array}{l}\text { Lava lake surface within CP already cooled } \\
\text { significantly }\end{array}$ \\
\hline 11 & April 2 & & $\mathrm{~V}$ & $\begin{array}{l}\text { No thermal anomaly; dense cloud } \\
\text { coverage }\end{array}$ & No evidence of renewed activity \\
\hline \multirow[t]{5}{*}{12} & April 3 & $\begin{array}{l}\text { Terra: } 6 \text { pix. } \\
\text { (10:50 A.M.) }\end{array}$ & $\mathrm{X}$ & $\begin{array}{l}\text { Multiple intense anomalies at summit } \\
\& \text { on W flank }\end{array}$ & $\begin{array}{l}\text { Second eruption peak: second lava flood in crater } \\
\& 3 \mathrm{~km} \text { long flow down } \mathrm{W} \text { flank, over first one }\end{array}$ \\
\hline & & $\begin{array}{l}\text { Aqua: } 6 \text { pix. } \\
\text { (1:45 P.M.) }\end{array}$ & $\mathrm{X}$ & & \\
\hline & & $\begin{array}{l}\text { Terra: } 9 \text { pix. } \\
\text { (11:10 P.M.) }\end{array}$ & V & & \\
\hline & & $\begin{array}{l}\text { Aqua: } 14 \text { pix. } \\
\text { (2:10 A.M.) }\end{array}$ & $\mathrm{V}$ & & \\
\hline & April 4 & $\begin{array}{l}\text { Aqua: } 4 \text { pix. } \\
\text { (2:30 P.M.) }\end{array}$ & $\mathrm{X}$ & $\begin{array}{l}\text { Moderate intensity anomalies on lower } \\
\mathrm{W} \text { flank }\end{array}$ & Lava cooling on W flank \\
\hline 13 & April 5-12 & & $\mathrm{V}$ & $\begin{array}{l}\text { No thermal anomaly; dense cloud } \\
\text { coverage }\end{array}$ & $\begin{array}{l}\text { No evidence of thermal activity, end of lava lake } \\
\text { activity }\end{array}$ \\
\hline
\end{tabular}

Numbers in first column refer to Fig. 4g. Scenes marked with a V or with X are night-time and day-time acquired, respectively. Night-time scenes were analysed using MODLEN. Thermal anomalies were visually identified on daytime scenes. Night-time data were acquired for the night between the mentioned date and following day 
below the undercut flank of T57. These ellipsoidal cavities represent direct evidence for shallow subsurface magma ponds, now drained. The $\mathrm{CP}$ walls are made up of altered flows, spatter layers and former lava lakes.

At its $\mathrm{S}$ rim, the CP is breached by a $\sim 10-\mathrm{m}$-deep, $1-\mathrm{m}$ wide canyon, which splits into three branches before reaching the near-flat $\mathrm{S}$ area of the crater (Figs. 1 and 3c). Lava channels extending into the near-flat crater area indicate that these canyons fed the main flow covering the crater, which subsequently flowed down the $\mathrm{W}$ flank. As all emplaced lava in the eruption passed through these canyons, the effusion rate in these was very high. The near-vent environment means that very limited cooling or crystallisation could have affected the initial viscosity. As turbulent lava flows are favoured by high effusion rates and low viscosity, the narrow and deep incision into the CP S wall is consistent with thermal erosion by turbulently flowing lava exiting from the $\mathrm{S}$ base of T58C (Fig. 3b). Gradual canyon deepening led to drainage of the CP lava lake.

\section{New lava field in the crater}

The March 25-April 5 eruption formed a virtually flat lava field in the $\mathrm{S}$ third of the crater (Fig. 1). Lava surface textures are smooth/ropy pahoehoe to scoriaceous rubbly pahoehoe/aa-like lava (i.e. $<10-\mathrm{cm}$-scale surface roughness). Several overlapping flow units can be discriminated. There is little indication of any flow direction outside the lava channels (see hereafter), except for some late-stage ropy pahoehoe lobes. The lava field appears to have emplaced rapidly and inflated at a late stage by additional input at a lower rate beneath the cooled crust.

Well-defined lava channels are identified in the flow field. These channels are 2- to 3-m wide, i.e. exceptionally large by OL standard. They are characterised by laminar flow features (i.e. parabolic surface pattern indicating latest velocity profile), by a finely scoriaceous surface and by smooth pahoehoe channel overflows. Late-stage flows in the channels display inflated pahoehoe lobes $(0.1$ to $\sim 1-\mathrm{m}$ thick) and pressure-ridges (see Mattsson and Hode Vuorinen 2008). The 30 - to 60 -cm-deep channels are bordered by overhanging walls. The channel morphology is typical of thermally eroded channels formed by turbulent flows at high discharge rate (Jarvis 1995) as described for komatiite flows (e.g. Huppert et al. 1984; Huppert and Sparks 1985). Thermally eroded lava channels can also form laminarly, as documented at OL by Pinkerton et al. (1995), but these channels were of a much smaller scale (dm-scale) than documented in this study. On balance, it seems unlikely that the m-scale thermally eroded channels we observed could have formed in the laminar regime.

Close to the $\mathrm{W}$ overflow, the channels merge into a single channel that deepens abruptly from $50 \mathrm{~cm}$ to $2.5 \mathrm{~m}$ and widens to $5 \mathrm{~m}$ (Fig. $5 \mathrm{~b}$ ). Directly beyond the crater rim, a $20 \times 20 \mathrm{~m}, \sim 5-\mathrm{m}$ deep depression, formed by thermal erosion as lava overflowed the rim. An additional channel starting at T37B base suggests that lava also issued from that hornito during the eruption (Fig. 1). April 1 photographs (Fig. 3b) indicates that these channels formed during the second eruption phase.

The main flow field is $60-90 \mathrm{~cm}$ thick against the crater $\mathrm{S}$ wall, but only $10 \mathrm{~cm}$ thick at its $\mathrm{N}$ edge, consistent with rapid emplacement. In its central part, it covers an old cone (T30), indicating lava accumulation up to $2.5 \mathrm{~m}$. In the channel walls close to the crater overflow, the fresh lava is $1.8 \mathrm{~m}$ thick. With limited constraints on the original crater floor topography, an average thickness of $1.2 \pm 0.3 \mathrm{~m}$ is taken as a conservative estimate, leading to a volume for the main flow field in the crater at $4.5 \pm 1.2 \times 10^{4} \mathrm{~m}^{3}$ (Table 3).

In the SW part of the flow field, one flow can be discriminated based on its greater thickness, darker colour and slabby pahoehoe texture (i.e. $\sim 1-\mathrm{m}$-scale vertical surface irregularities; Figs. 1 and $5 \mathrm{c}$ ). This unit was associated with the first eruption phase (April 1 photograph; Fig. 3b). This flow unit shows evidence of compression against the $\mathrm{S}$ crater wall, as it is thicker there. It was observed by local guides to remain hotter and to degas for a longer period after the eruption compared to the rest of the field. This flow is 1.3 to $1.8 \mathrm{~m}$ above the surrounding lava plain and up to $2.3 \mathrm{~m}$ above the former surface. It represents a significant lava volume (Table 3 ). Its extrusion point is ill-defined. Its proximal extension disappears under lava emplaced later.

Three thick aa-like flows, distinct from the main field, were associated with the second eruption phase (Fig. 3b). Two of these flows (FL1 and FL2; Fig. 1) extended W from the CP. They are characterised by a $\sim 6-\mathrm{m}$-wide, $2-\mathrm{m}$-thick flow channel in their proximal section and by a $>15-\mathrm{m}-$ wide lobe in the distal section, up to $1 \mathrm{~m}$ thick. A third flow (FL3) issued from T37B base and extended to SE. The small volume of these flows (Table 3) compared to the main field is consistent with late-stage emplacement, when little magma remained in the shallow reservoirs.

\section{West flank lava flows}

Most of the erupted volume exited the crater to flow down the $\mathrm{W}$ flank (Fig. 7). The flow was confined within a deep gully extending down the $30-35^{\circ}$ steep flank. From observations in the lower gully, it is estimated that it was originally $\sim 20 \mathrm{~m}$ deep and $\sim 15-20 \mathrm{~m}$ wide (Fig. $5 \mathrm{~d}$ ). Lava filled the gully to more than half its depth. At $1,700 \mathrm{~m}$ elevation $(\sim 1,100 \mathrm{~m}$ below the crater rim) the flow reached more gentle slopes $\left(10-15^{\circ}\right.$ slopes) and overtopped gully sides. It formed a $1.3-\mathrm{km}$-long and 100 - to 150 -m-wide 

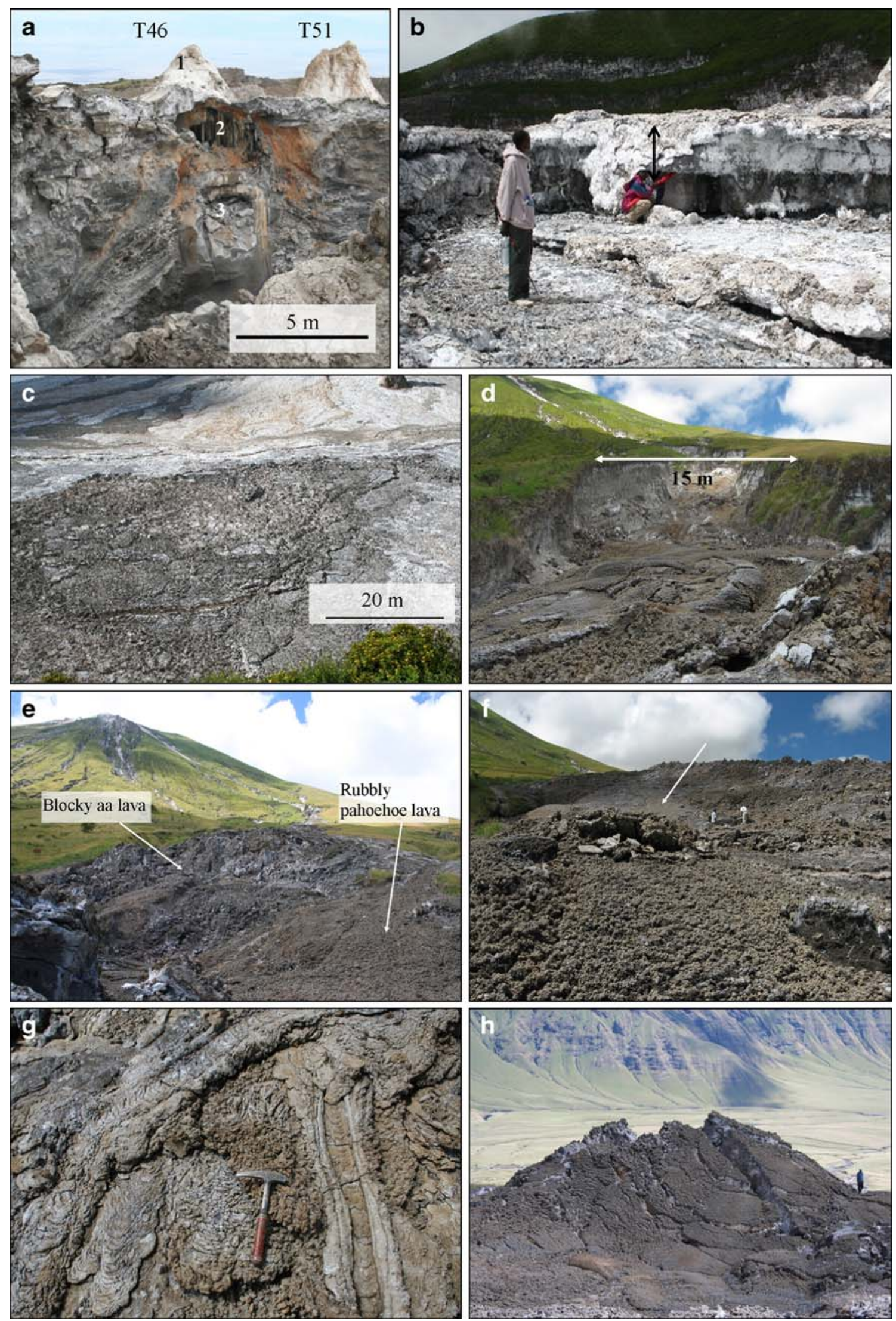
Fig. 5 a W section of CP1 crater wall cutting through hornito T46 (1). A cavity within the hornito (2) and a solidified shallow magma reservoir directly underneath the cavity (3) are observed. b A 2-mdeep, 5-m-wide lava channel close to crater rim (inside the crater). The channel cuts into an older lava flow, with the fresh flow being $\sim 1.2 \mathrm{~m}$ thick (black double arrow). $\mathbf{c}$ Thick slabby pahoehoe flow in SW part of the crater. d Photograph looking up towards OL summit, at $\sim 1,800 \mathrm{~m}$ a.s.l; lava flow is confined by a $\sim 15$-m-wide canyon. e Looking in the same direction at $\sim 1,650 \mathrm{~m}$, lava flows have a complex texture: blocky aa lava (to left) and finely rubbly pahoehoe lava (to right). f Remnant of a lava tube roof (white arrow; people in white shirt for scale). $\mathbf{g}$ Outbreaks of small pahoehoe flows from a stagnated flow front with well-formed levees and central channels (hammer for scale). h $10 \mathrm{~m}$ high tumulus at 1,680 $\mathrm{m}$ a.s.l. cut by axial and radial inflation clefts

lobe with a well-defined front. The flow is $12 \mathrm{~m}$ thick in the central part of this distal lobe (Fig. 2b).

The relationships between different flow morphologies in the gully are complex and can change considerably over a few meters (Fig. 5e). Most of the flows are of rubbly pahoehoe type (with inflation features) or blocky aa-type. A clear separation of different flow types is, however, difficult, as rubbly pahoehoe ranges from slightly scoriaceous, with some ropy textures to more scoriaceous, approaching aa-type surfaces. At one location within the flank flow, a major lava tube is exposed (Fig. 5f). Smallvolume flows and outbreaks originating from stagnating fronts formed at a late stage. These flows are markedly different in morphology, with ropy to smooth pahoehoe surfaces dominating, in small channels (5-20 cm wide) with well-developed levees (a few cm high; Fig. 5g).

At the flow front (at $1,400 \mathrm{~m}$ a.s.1), the lava is $\sim 2 \mathrm{~m}$ thick. Thin flows extrude from the front and extend several hundred meters along small gullies (i.e. $\sim 5 \mathrm{~m}$ wide; Fig. 2b). These flows are less than $1 \mathrm{~m}$ thick, with a pahoehoe texture similar to that of late-stage outbreaks in the uppermost parts of the main lava lobe. Their volume is small $\left(<10^{3} \mathrm{~m}^{3}\right)$. As observed in the 1993 aa flow (Dawson et al. 1994), small, mobile pahoehoe flows are sourced from the front of a more massive flow. Such late-stage pahoehoe flows were shown to have a composition consistent with extreme fractionation (Pyle et al. 1991). The expectation is that these pahoehoe flows represent the residual melt from crystallisation and filter pressing/compaction of the lava during and possibly after flow as described by Keller and Krafft (1990). They can readily escape from the crystal mush of a stagnating aa flow due to their low viscosity (Norton and Pinkerton 1997).

A large, semi-circular tumulus formed in the upper parts of the flow lobe at $1,680 \mathrm{~m}$ elevation (Fig. 5h). The tumulus has curved outer surfaces and is cut by $>4 \mathrm{~m}$ deep, axial and radial inflation clefts. Three different types of flows can be identified from the axial cleft of the tumulus (Mattsson and Hode Vuorinen 2008). The lowermost $2.3 \mathrm{~m}$ of the cleft exposes the banded upper-vesicular crust of a tube-fed flow that inflated, followed by a scoriaceous horizon (20-40 cm thick). This is overlain by a rubbly pahoehoe flow, $1.8 \mathrm{~m}$ thick, that shows no signs of inflation itself but displays plastic deformation and gently curved outer surfaces produced as the underlying flow inflated. This upper flow has an internal structure with concentric vesicle bands and more vesicular interior, similar to S-type pahoehoe of Wilmoth and Walker (1993). The third flow type is represented inside the tumulus axial cleft as a small hornito (35 $\mathrm{cm}$ high and $15 \mathrm{~cm}$ in diameter) of highly vesicular natrocarbonatite.

The W flank flow volume is difficult to assess due to lack of detailed pre-eruption topography information (Table 3). A rectangular cross-section, $15 \pm 3 \mathrm{~m}$ wide and $10 \pm 2 \mathrm{~m}$ deep, is assumed for the gully-confined flow. The along slope gully length is $2.45 \mathrm{~km}$. The gully flow volume is thus estimated at $3.7 \pm 1.4 \times 10^{5} \mathrm{~m}^{3}$. In the distal flow lobe, thickness varies from a few centimetres at the edges to $\sim 12 \mathrm{~m}$ centrally. Using a conservative average thickness of $4 \pm 1 \mathrm{~m}$, a volume estimate of $4.8 \pm 1.5 \times 10^{5} \mathrm{~m}^{3}$ is obtained. The total volume of the $\mathrm{W}$ flank lava is at least 12 times the summit crater flow volume (Table 3).

Evolution after May 2006: Transition to explosive volcanism

Only one additional eruptive event was recorded at OL in 2006, after April 5 (on June 20, 2006; Table 1). It involved collapse of T37B (Figs. 1 and 6), formation of a second pit crater (CP2), and extrusion of a lava flow in the SE of the crater (Figs. 3d and 7). CP1 continued to enlarge gradually and, by June 2007, it had merged with CP2 (Fig. 6). Natrocarbonatite eruptions resumed by June 2007 (Table 1) after a year long hiatus in activity. Through July and August 2007, over 25 tectonic earthquakes of magnitude 4 to 5.9 on the Richter scale have been reported within $50 \mathrm{~km}$ of OL (based on teleseismic data; European-Mediterranean Seismological Centre website; www.emsc-csem.org). A series of explosive eruptions started on September 4, 2007, causing 2-3 km high ash columns, damage to the vegetation on the volcano slopes and ash fallout to at least $20 \mathrm{~km}$ from OL summit. Access to OL has been closed for visitors by local authorities (GVN 2007). Cycles of effusive to explosive volcanism have occurred repetitively at OL every few decades. Our study provides insights on how this can occur.

\section{Composition of March-April 2006 lavas}

Seventeen natrocarbonatite samples were collected during the field visit (May 25-26, 2006) of MK and FK. The 

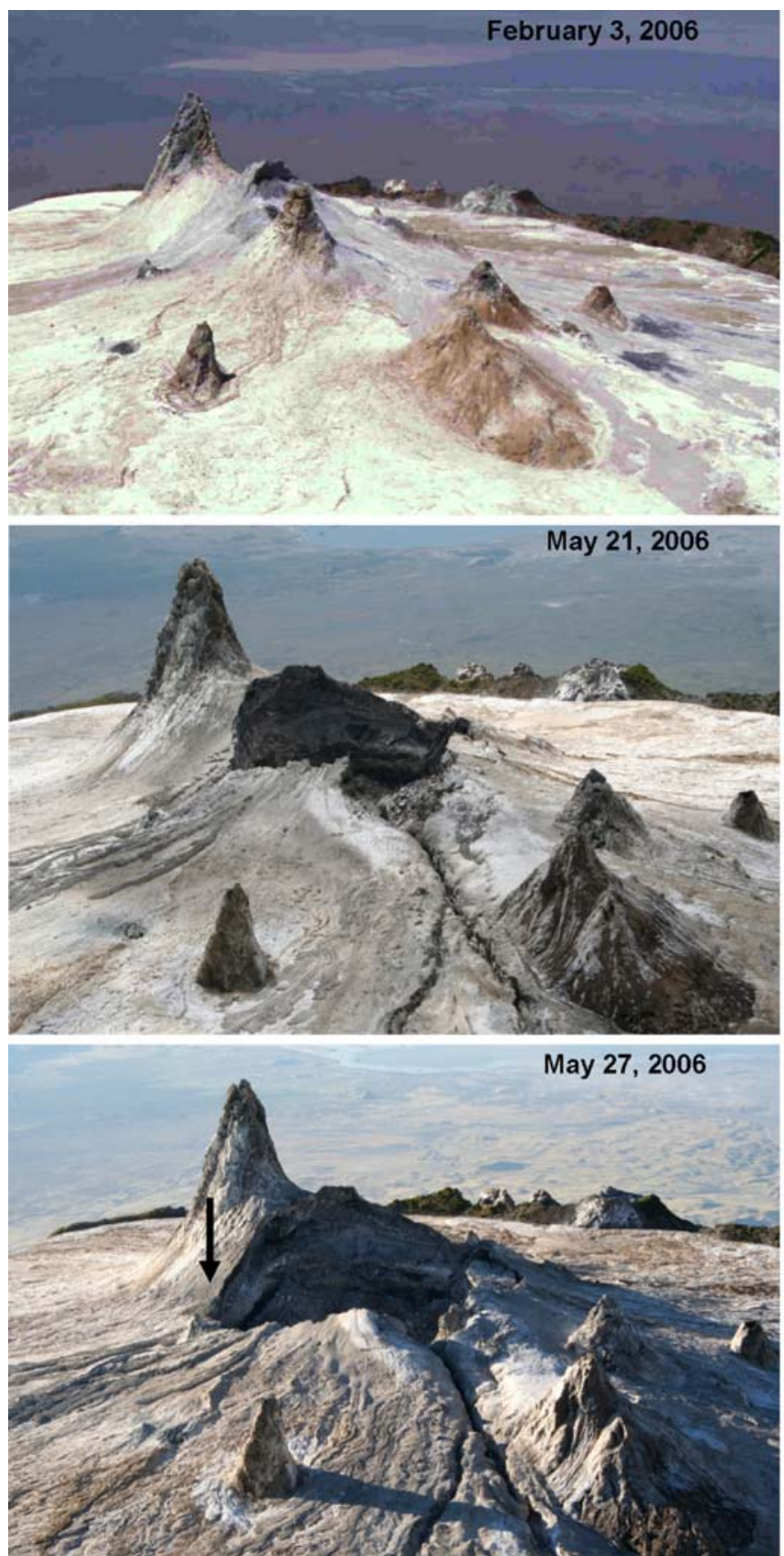

Fig. 6 Morphological evolution of central hornito cluster and of pit crater $(C P 1)$ from February 2006 to June 2007. CP1, formed on March 25, significantly enlarged throughout this period (black arrow). A second pit crater $(C P 2)$ is observed at the former location of hornito

samples show effects of rapid natrocarbonatite alteration as described by Zaitsev and Keller (2006). Even mere weeks after emplacement, neo-formation of trona, thermonatrite and nahcolite and efflorescences of halides are prominent. Petrographic inspection of seven water-free-prepared thin sections and chemical analysis of three of the freshest samples by X-ray fluorescence (XRF; Table 4) were carried out at University of Freiburg.
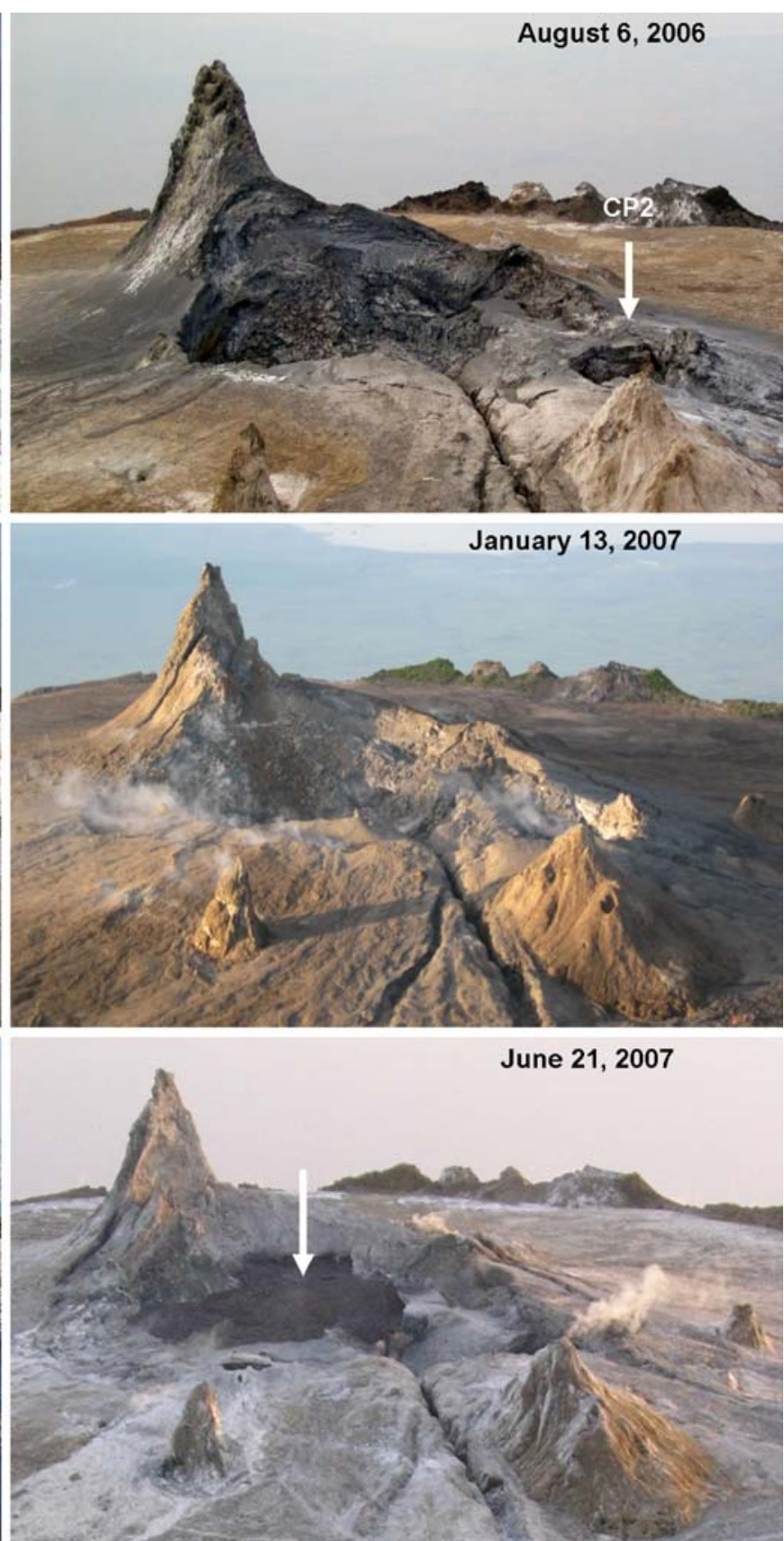

T37B on the August 6 photograph (white arrow). CP1 floor is covered by fresh lava in June 2007 (white arrow) (Photos courtesy of C. Weber, B. Masson and R. Nandedkar)

Petrographic description

All samples are similar to lavas of the ongoing eruptive period (lasting since 1983), regularly sampled since 1988 . This similarity refers to the phenocryst association of stubby rectangular laths of nyerereite and sub-rounded gregoryite, up to $1-2 \mathrm{~mm}$, set in an interstitial matrix of fine-grained nyerereite and gregoryite with skeletal 
Table 3 Thickness, area and volume of lava flow units from March 25-April 52006 eruptions

\begin{tabular}{|c|c|c|c|c|}
\hline Lava flow units & Area $\left(\mathrm{m}^{2}\right)$ & Min-max thickness (m) & Average thickness (m) & Volume $\left(\mathrm{m}^{3}\right)$ \\
\hline Main flow field within crater & $37.3 \pm 0.5 \times 10^{3}$ & $0.1-2.5$ & $1.2 \pm 0.3$ & $4.5 \pm 1.2 \times 10^{4}$ \\
\hline Thick flow in SW of crater & $11.7 \pm 0.5 \times 10^{3}$ & $1.3-2.3$ & $2 \pm 0.1$ & $2.3 \pm 0.2 \times 10^{4}$ \\
\hline FL1 (W of crater) & $1,175 \pm 50$ & $0.4-1.3$ & 0.8 & $940 \pm 40$ \\
\hline FL2 (SW of crater) & $2,500 \pm 100$ & $0.4-2.0$ & 0.8 & $2,000 \pm 80$ \\
\hline FL3 (SE of crater) & $750 \pm 50$ & $0.3-0.8$ & 0.6 & $450 \pm 20$ \\
\hline Total lava flow summit crater & & & & $7.1 \pm 1.4 \times 10^{4}$ \\
\hline Flow within gully on $\mathrm{W}$ flank & $36 \pm 7 \times 10^{3}$ & $?$ & $10 \pm 2$ & $3.7 \pm 1.4 \times 10^{5}$ \\
\hline Flow lobe on lower W flank & $12 \pm 1 \times 10^{4}$ & $0-12$ & $4 \pm 1$ & $4.8 \pm 1.5 \times 10^{5}$ \\
\hline Total lava flow on W flank & & & & $8.5 \pm 2.9 \times 10^{5}$ \\
\hline Total & & & & $9.2 \pm 3.0 \times 10^{5}$ \\
\hline
\end{tabular}

Areas were estimated from GPS survey in the field and from an ASTER satellite image (Fig. 7). Average thickness and volume of FL 1-3 were estimated from topographic profiles across the flows
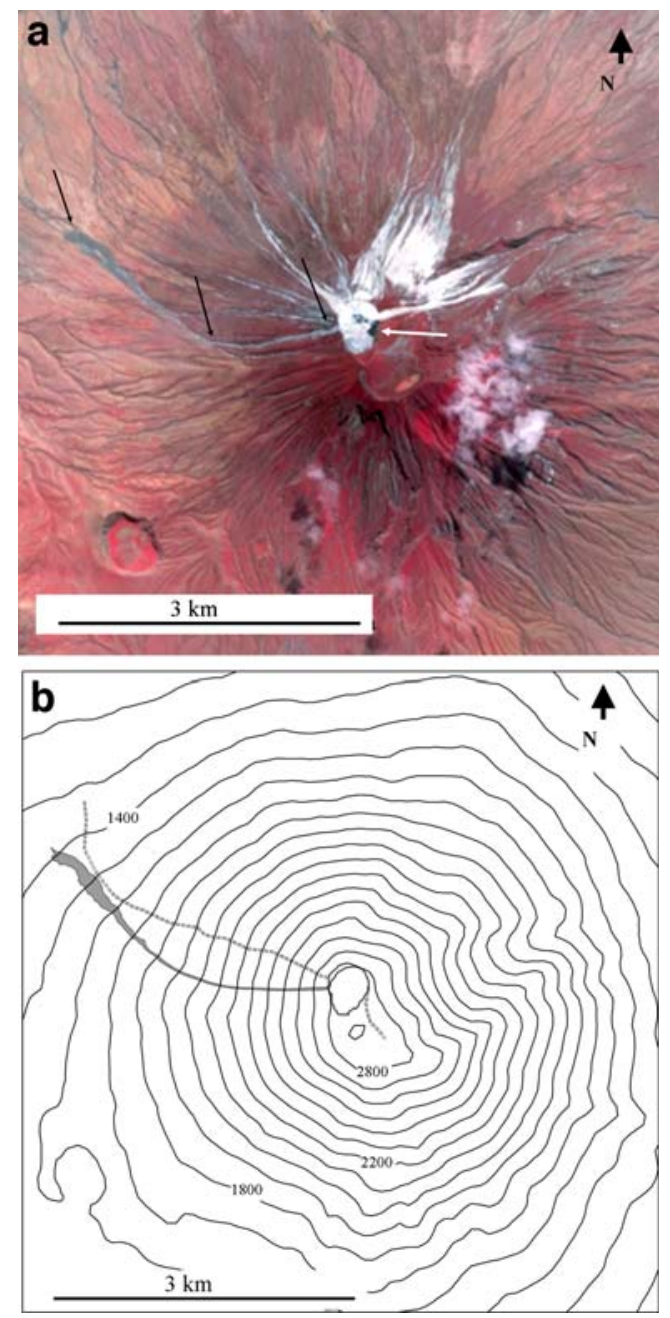

Fig. 7 a Colour composite of ASTER visible and near infrared bands (red: band 3, 0.78-0.86 $\mu \mathrm{m}$; green: band 2, 0.63-0.69 $\mu \mathrm{m}$; blue: band $1,0.52-0.60 \mu \mathrm{m})$ acquired on June 29,2006 . The flow emplaced during the March 25-April 5 eruption is visible on W flank. Locations of crater rim overflow, exiting from $\mathrm{W}$ flank gully and flow front are marked by black arrows. b Map of same flow with $100 \mathrm{~m}$ contour intervals extracted from SRTM DEM. Stippled line marks the track to climb the flank from W. Dark area to SE of crater (white arrow in a) corresponds to June 20, 2006 lava flow fluorite and finely dispersed opaques. Sylvite/halite appear in XRD patterns. Reference is made to thin section photographs in McKie and Frankis (1977), Keller and Krafft (1990), or Peterson (1990). Most samples for the present study are phenocryst-rich (up to $60 \%$ ), with little groundmass.

Silicate spheroids, up to $1 \mathrm{~mm}$ in thin sections, are present and consist of nepheline, pyroxene, Ti-andradite and wollastonite. Typically single crystals or glomerophyric blobs of these minerals form cores surrounded by finegrained silicate matrix of the same minerals with combeite and opaques. The spheroids correspond to the combeitewollastonite nephelinites of the younger OL stage (Klaudius and Keller 2006). Pseudomorphs in the fine grained matrix of the spheroids can be interpreted as former groundmass melilite, relating spheroids even more directly to silicate lapilli of historical eruptions. To a varying degree, natrocarbonatite melt infiltrated these spheroids. Based on silica content of samples (see hereafter), the proportion of silicate spheroids is estimated to range from $\sim 3$ to $\sim 7 \%$ for OL-1 and OL-S2, respectively.

Sample OL-6 is devoid of silicate spheroids. In contrast, most other samples of the 2006 eruption period collected in the products from the crater or $\mathrm{W}$ flank flow, in particular samples OL-1 and OL-S2 (Table 4), show silicate spheroids as described for the exceptional 1993 eruptions (Dawson et al. 1994; Church and Jones 1995).

\section{Chemical composition}

Table 4 compares three analyses of 2006 lavas with a natrocarbonatite composition from Keller and Zaitsev (2006) representative of the last years. Whereas sample OL-6 from 2006 compares well in major element composition and in all analysed trace elements with this selected reference, samples OL-1 and OL-S2 show a distinct silicate component as expected from thin section observations of a significant spheroids content. Both the spheroid content and 
Table 4 Chemical composition of three lava samples for the March 2006 eruption, and of reference samples, used for comparison
OL259 Representative natrocarbonatite composition; Lava from T49 on October 9, 2000, from Keller and Zaitsev (2006). OL-6 Lava flow sample collected on May 26, 2006, at $2,827 \mathrm{~m}$ a.s.1, W crater rim. $O L-1$ Lava flow sample collected on May 25, at 1,562 m a.s.l, at the flow margin on $\mathrm{W}$ flank. $O L-S 2$ Lava flow sample collected on May 26 at $2,825 \mathrm{~m}$ a.s.l, in SW part of the crater, within thick dark slabby pahoehoe flow unit (see text). $O L-F-35$ Spheroid-bearing viscous lava flow of 1993 ("Chaos Crag" Flow, Dawson et al. 1994), unpublished analysis by J. Keller on sample collected by P. Vetsch, Geneva. bd: below detection limit. All analysis by XRF were done at MGI Freiburg. Trace elements in $\mathrm{ppm}$

\begin{tabular}{|c|c|c|c|c|c|}
\hline Sample & OL-259 & 2006 OL-6 & 2006 OL-1 & 2006 OL-S2 & OL-F-35 \\
\hline Eruption & Oct. 2000 & March 2006 & March 2006 & March 2006 & June 1993 \\
\hline $\mathrm{SiO}_{2}$ & 0.23 & 0.19 & 1.48 & 3.45 & 3.06 \\
\hline $\mathrm{TiO}_{2}$ & 0.02 & 0.01 & 0.04 & 0.07 & 0.10 \\
\hline $\mathrm{Al}_{2} \mathrm{O}_{3}$ & 0.00 & 0.00 & 0.39 & 1.01 & 0.84 \\
\hline $\mathrm{Fe}_{2} \mathrm{O}_{3} \mathrm{t}$ & 0.44 & 0.37 & 0.94 & 1.24 & 1.41 \\
\hline $\mathrm{MnO}$ & 0.47 & 0.47 & 0.38 & 0.35 & 0.37 \\
\hline $\mathrm{MgO}$ & 0.43 & 0.50 & 0.41 & 0.49 & 0.49 \\
\hline $\mathrm{CaO}$ & 15.11 & 14.91 & 17.64 & 16.50 & 16.83 \\
\hline $\mathrm{SrO}$ & 1.46 & 1.31 & 1.26 & 1.21 & 1.26 \\
\hline $\mathrm{BaO}$ & 1.54 & 1.21 & 0.99 & 0.91 & 1.06 \\
\hline $\mathrm{Na}_{2} \mathrm{O}$ & 32.74 & 31.96 & 30.98 & 31.15 & 30.42 \\
\hline $\mathrm{K}_{2} \mathrm{O}$ & 8.30 & 8.62 & 6.76 & 6.73 & 6.89 \\
\hline $\mathrm{P}_{2} \mathrm{O}_{5}$ & 0.75 & 0.84 & 1.03 & 1.01 & 1.04 \\
\hline $\mathrm{CO}_{2}$ & 30.56 & 31.15 & 32.16 & 30.32 & 30.70 \\
\hline $\mathrm{Cl}$ & 4.12 & 4.54 & 1.73 & 1.54 & 1.57 \\
\hline $\mathrm{SO}_{3}$ & 2.80 & 2.22 & 1.75 & 2.81 & 1.80 \\
\hline $\mathrm{F}$ & 3.03 & 2.50 & 2.82 & 2.61 & 2.69 \\
\hline $\mathrm{H}_{2} \mathrm{O}$ & 0.01 & 0.47 & 0.16 & 0.23 & 0.02 \\
\hline$. / \mathrm{F}, \mathrm{Cl}$ & -2.21 & -2.08 & -1.58 & -1.45 & -1.49 \\
\hline Total & 99.80 & 99.19 & 99.34 & 100.19 & 99.06 \\
\hline $\mathrm{Rb}$ & 195 & 161 & 143 & 139 & 134 \\
\hline $\mathrm{Sr}$ & 12330 & 11075 & 10650 & 10213 & 10655 \\
\hline $\mathrm{Ba}$ & 13759 & 10825 & 8845 & 8189 & 9481 \\
\hline $\mathrm{Pb}$ & 69 & 98 & 92 & 67 & 74 \\
\hline Th & 6 & 8 & 6 & 9 & 9 \\
\hline $\mathrm{U}$ & 14 & 13 & 10 & 12 & 12 \\
\hline $\mathrm{Nb}$ & 30 & 37 & 70 & 93 & 90 \\
\hline $\mathrm{Zr}$ & bd & bd & bd & bd & 71 \\
\hline $\mathrm{Y}$ & 8 & 12 & 11 & 17 & 19 \\
\hline $\mathrm{V}$ & 189 & 144 & 133 & 134 & 152 \\
\hline $\mathrm{La}$ & 646 & 606 & 418 & 434 & 426 \\
\hline $\mathrm{Ce}$ & 790 & 774 & 769 & 607 & 617 \\
\hline $\mathrm{Nd}$ & 122 & 121 & 122 & 112 & 119 \\
\hline
\end{tabular}

chemical composition relate the March 2006 natrocarbonatite to the so far exceptional 1993 compositions. Sample OL-F-35 in Table 4 represents the silicate spheroid-bearing lava of 1993 (i.e. the so-called Chaos Crag flow of Dawson et al. 1994). The composition compares closely with that of our OL-S2 sample, collected within the thick slabby pahoehoe flow unit of the crater. OL-1, collected from $1,562 \mathrm{~m}$ elevation at the margin of the $\mathrm{W}$ flank flow, is intermediate between natrocarbonatite (e.g. OL-6) and more $\mathrm{SiO}_{2}$-rich compositions (e.g. OL-S2 and OL-F-35).

\section{Interpretation of the eruptive events}

Eruption chronology

Accounts from Engare Sero authorities and MODIS data point to the start of the main eruption phase on March 25. It was characterised by a loud "explosion" sound, arguably accompanied by a dilute dust plume, mistaken for ash. These events are attributed to collapse of two central hornitos (T56B and T58B) forming a caldera-like pit crater (CP1). It was directly followed by rapid lava lake drainage, flooding part of the crater and by rapid flow emplacement on the flank. Maximum flow length was reached, based on MODLEN evidence and field accounts, in less than $20 \mathrm{~h}$. The thundering collapse noise heard by villagers even far away from OL was mistakenly reported as the start of an explosive eruption.

MODIS data suggest a significant lava volume was already emitted as early as March 22. Although these flows have not been observed, they were probably emitted from breaches in the hornitos' flanks, reducing the stability of the overlying hornitos. The emplacement, before April 1, of the thick slabby pahoehoe flow in the SW of the crater is not well constrained in time but probably immediately followed the March 25 collapse. 
From March 27 to April 2, MODIS data suggest that activity was confined to a lava lake in CP1, while the flank lava was cooling down. Field observations of the tumulus on the flank flow, however, show that much of the crater overflow was emplaced in a lava tube, with inflation of an already cooled crust. Field evidence suggests that the tumulus was actively inflating for most of the eruption duration (Mattsson and Hode Vuorinen 2008). Tube-fed flows would neither have been detected by MODIS nor by ground observers some kilometres away. Lava lake activity decreased over time, probably sourcing the flank lava tube at a decreasing rate.

Eruptive activity resumed on April 3 with a second effusive eruption. It was most probably triggered by a further hornito collapse (i.e. part of T58C) into the lava lake. The lava again exited the lake through the $\mathrm{S}$ canyon, deepening it further through thermal erosion. The lava, mostly confined to channels within the crater, rapidly flowed down the flank, mainly through the existing lava tube. The flow reached its final length by April 4. The lava lake continued to degas for at least 5 additional days. Three isolated aa flows observed to the $\mathrm{W}$ and $\mathrm{E}$ of the collapse crater (FL1, 2 and 3; Fig. 1) are thought to have emplaced during this late eruption phase. Eruption end might have been associated with the collapse of T58C remnants by April 10-12.

\section{Erupted volume and feeder system}

The total volume emitted in the March 25-April 5 eruptions is exceptionally large by OL standard $\left(9.2 \pm 3.0 \times 10^{5} \mathrm{~m}^{3}\right.$; Table 3 ), $92 \%$ of it being emplaced onto the flank. This lava volume is six times larger than the voluminous flows of 1993 (Dawson et al. 1994). The 2006 lava was emplaced in less than 14 days (March 22-April 4), suggesting a minimum average eruption rate of $0.8 \mathrm{~m}^{3} \mathrm{~s}^{-1}$, i.e. nine times larger than the average eruption rate estimated for the 1993 event. Assuming that the two peak eruption phases of March 25 and April 3 lasted 5-20 h, as suggested by MODIS data, and were each responsible for one fourth of the total lava volume, eruption rates of $3-12 \mathrm{~m}^{3} \mathrm{~s}^{-1}$ or higher occurred. These peak rates are similar to the largest rates previously reported at $\mathrm{OL}$ for eruptive events lasting less than an hour $\left(5-10 \mathrm{~m}^{3} \mathrm{~s}^{-1}\right.$; GVN 2005a). These previous events were also associated with hornito flank collapse and shallow reservoir drainage.

There are striking similarities between the June 1993 and March-April 2006 eruptions (Dawson et al. 1994, 1996; Church and Jones 1995). Although eruption volumes and rates differ by an order of magnitude, both events were of much larger volume and eruption rate than usual natrocarbonatite eruptions at OL. In both cases, the lava was crystal-rich and contained silicate spheroids, although not for all 2006 samples. This suggests higher variability in the magma source for the 2006 eruption.
The June 1993 eruption was associated with explosive activity forming several ash cones within the crater, whereas the March-April 2006 eruption was associated with breaching of shallow magma reservoirs probably triggered by hornito collapse and was not associated with ash deposits. Dawson et al. (1994) suggest very high apparent viscosity (i.e. $10^{7}-10^{8} \mathrm{~Pa} \mathrm{~s}$ ) for the 1993 lava compared to usual natrocarbonatite lavas (Dawson et al. 1990) due to the high crystal content and lava ponding within the crater. For the March-April 2006, emplacement onto the $\mathrm{W}$ flank of a $3-\mathrm{km}$ long flow in less than a day suggests that apparent viscosity was much lower than for the 1993 event. Mattsson and Hode Vuorinen (2008) indeed estimated the flow viscosity at $10^{2}-10^{3} \mathrm{~Pa}$ s only slightly higher than other field and laboratory estimates of natrocarbonatite lava viscosity $(0.3-120 \mathrm{~Pa} \mathrm{~s}$; Dawson et al. 1990; Pinkerton et al. 1995; Norton and Pinkerton 1997). The large lava tube, established in the first effusive event in March 2006 and probably active for the entire eruption (Mattsson and Hode Vuorinen 2008), led to slower lava cooling.

The June 1993 eruption was followed by 8-14 months without any lava emission and by gradual formation of an 100-m-diameter, 20-m-deep depression at the crater centre (GVN 1994). A similar eruptive activity hiatus of about a year (i.e. after the June 20, 2006, event) and enlargement of the central pit crater have been observed after the MarchApril 2006 eruptions. This suggests that large volume eruptions drain most of the magma stored at shallow depth and that replenishment requiring $\sim 1$ year has to take place from depth, before activity resumes.

Available field evidence (i.e. shallow reservoirs in CP's walls, CP formation) and reconstructed eruption chronology (i.e. rapid lava drainage following collapse noise) are consistent with magma erupting after shallow level storage. The CP volume, assuming a cylindrical shape of $100 \mathrm{~m}$ diameter and $40 \mathrm{~m}$ depth (i.e. estimate based on the $85-\mathrm{m}-$ wide and 20- to 25-m-deep, still-enlarging pit filled up by scree material), can account for $\sim 35 \%$ of the total erupted volume. This $\mathrm{CP}$ volume can account for the first main lava emitted, i.e. by massive drainage of a shallow magma reservoir caused by the first hornito collapse on March 25 .

The lava that erupted in the second phase was most probably already present at shallow level underneath the hornito cluster. Interconnections between these closely spaced reservoirs could have caused their drainage into the CP. Based on the radius of the central hornito cluster, the dimensions of this agglomerate of magma reservoirs might approach $200 \times 150 \mathrm{~m}$, accounting for a magma volume of $\sim 9 \times 10^{5} \mathrm{~m}^{3}$, assuming an average reservoir thickness of $40 \mathrm{~m}$. In this scenario, the volume erupted was entirely contained in the shallow magmatic system underneath the central hornito cluster. If so, it could be expected 
Fig. 8 Conceptual, schematic sketch of evolution of central hornito cluster and shallow reservoirs during March-April 2006 eruptions. A hornito cluster with shallow interconnected reservoirs formed in the years before 2006. a Initial lava flows, from hornito flanks, lower reservoir magma levels and destabilize hornitos through the network of interconnected, probably stratified magma reservoirs (March 22-24); b T56B/ T58B collapse causing magma mixing, rapid reservoir drainage through thermally eroded canyon at $\mathrm{T} 58 \mathrm{C}$ base, emplacing lava flows in S part of crater and along flank; c lava drainage from interconnected reservoirs forms CP1 lava lake, T58C collapse causes second main lava surge. After eruption ends, CP1 continues to enlarge until June 2007, causing partial collapse of T49B. Shallow reservoir replenishment, evidenced by activity resumption in June 2007, marked end of $\mathrm{CP} 1$ enlargement a March $22-24,2006$

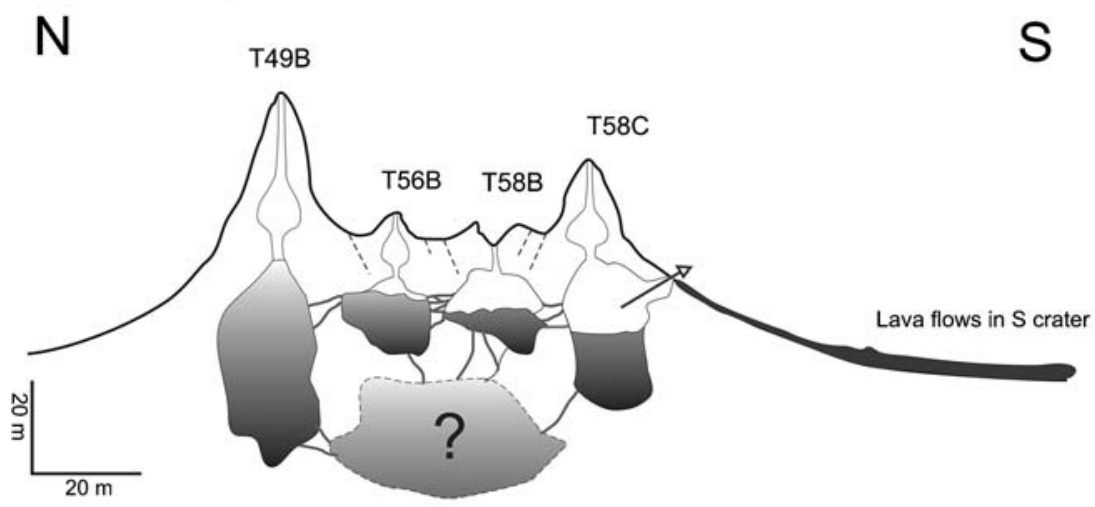

b March 25, 2006

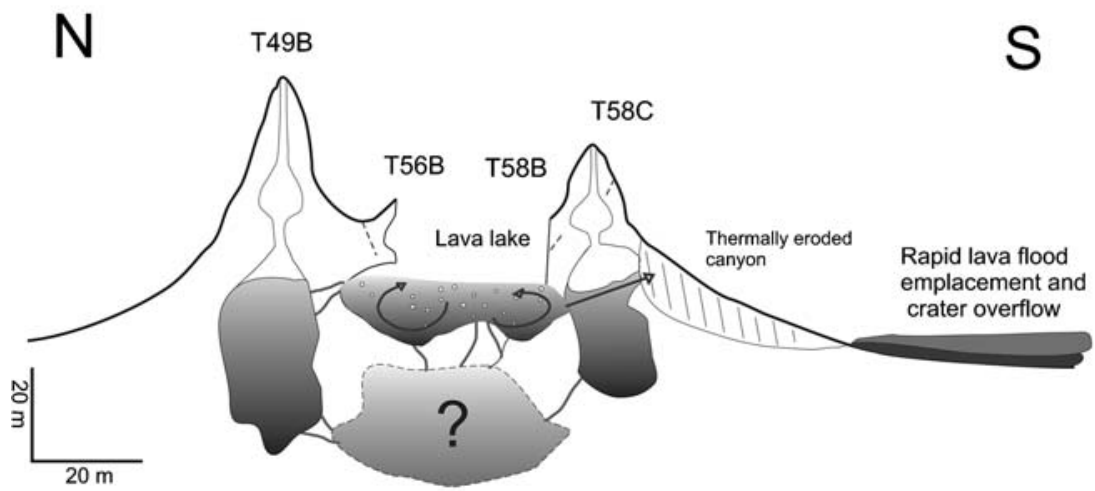

C April 3, 2006

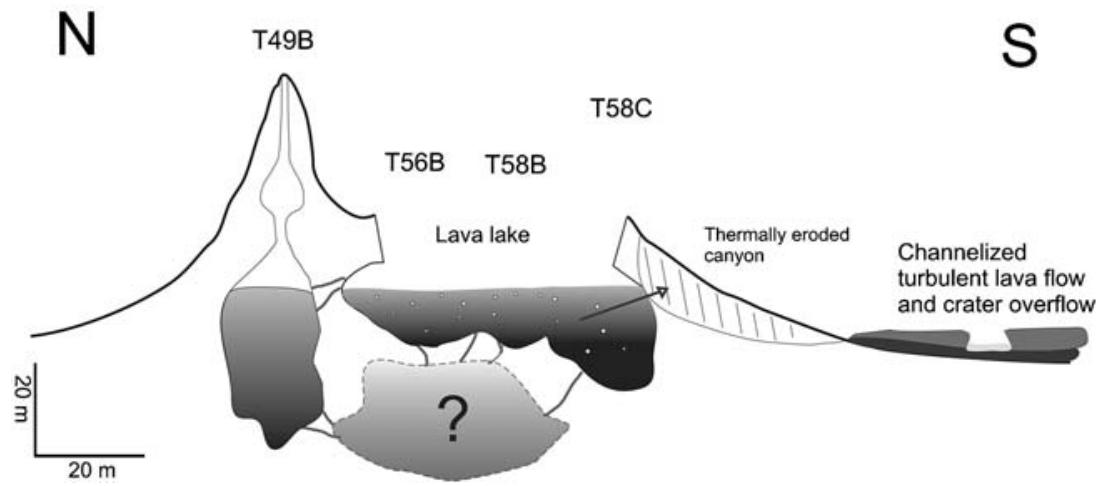

that the pit crater would continue to enlarge to form a $200 \times$ $150 \mathrm{~m}$ pit crater, causing collapse of the remaining hornitos. Replenishment of the shallow reservoirs can slow down or stop further pit enlargement. Explosive eruptions that started on September 2007 drastically changed the crater morphology, stopping this evolution (GVN 2007).

Another possible scenario is that the second phase occurred after replenishment of the shallow system by deeper magma. Assuming half the total volume erupted in the second phase, an average magma input in the shallow lava lake of $0.8 \mathrm{~m}^{3} \mathrm{~s}^{-1}$ must be assumed between the two phases. This magma volume corresponds to a spherical reservoir of at least $50 \mathrm{~m}$ radius. Although there are no additional observations to constrain the structure of the magmatic system within OL, Pyle et al. (1995) proposed a larger reservoir at an unknown depth within OL. Magma replenishment leading to resuming activity took more than 1 year after the March-April 2006 eruptions. This suggests characteristic timescales for substantial ascent from depth which far exceed 1 week and that replenishment rates are very low. On balance, all current evidence point to the first scenario. 
A conceptual model for the March-April 2006 eruptions

A conceptual model is proposed to account for the eruption evolution (Fig. 8). Each hornito tends to be associated with a very shallow (2-10 $\mathrm{m}$ deep) magma reservoir or subsurface lava lake with diameter matching the cone base size, as first deduced by Pyle et al. (1995). In recent years before March 2006, activity has often been intense and led to a high vent construct density at the surface atop a zone of elevated ground and to interconnection of many small reservoirs underlying individual hornitos (Fig. 8a). To our knowledge, such network of shallow, closely spaced, mscale reservoirs, feeding individual hornitos, have not been described for other volcanoes. Partial drainage of a reservoir through a hornito's flank at the eruption start (March 22-24) destabilized the overlying hornitos (Fig. 8a). The reservoirs' top was $\sim 10 \mathrm{~m}$ above the average crater elevation, allowing lava flow through the flank breach in T58C. Collapse of two hornitos (T58B and T56B) into the reservoirs triggered rapid drainage of a large volume, through the $\mathrm{T} 58 \mathrm{C}$ base.

Silicate spheroids in the lava could suggest that silicaterich melt was present at the bottom part of stratified shallow reservoirs. Hornito collapse triggered mixing of this stratified reservoir, incorporating spheroids into the dominantly natrocarbonatite melt. Spheroids could also be consistent with new silicate melt entering the shallow magmatic system and triggering the first voluminous lava extrusion (Keller and Krafft 1990). Evidence is insufficient to favour one or the other scenario. Syn-eruptive deepening of the thermally eroded canyon favoured drainage of the reservoir's deeper part (Fig. 8b). In the crater, eruption first produced high discharge lava floods to form the lava expanse covering one third of the crater and feeding the flank overflow. Interconnection of shallow reservoirs allowed lava lake refilling in the pit crater. The second peak eruption was associated with T58C partial collapse, triggering further lava lake drainage (Fig. 8c). Lava was then emplaced at lower rates (still much higher than usual) forming channels and individual aa flows. Final lava emplacement in the channels was at lower rate enabling laminar flow and deformation. The fact that collapse is occurring in a succession of events rather than all at once is more consistent with many small subsurface reservoirs, locally interconnected and with possible drainage from one to the others, rather than with a unique large and shallow reservoir under the elevated zone with dense vent construct concentration.

Based on depth measurements for the tumulus axial cleft, the time required for flank flows to solidify can be estimated with a conductive heat loss model (Carslaw and Jaeger 1959), using published physicochemical properties for natrocarbonatitic lava (Pinkerton et al. 1995). As estimated by Mattsson and Hode Vuorinen (2008) the total crust thickness exposed in the tumulus would have required nearly 2 years to solidify using published thermal diffusivity values for natrocarbonatite lavas. It follows that inflation must also have been ongoing during these 2 years. Although the flow clearly did not inflate over a period of 2 years, it is sufficient to suggest that active inflation occurred for most of the eruption.

\section{Eruption hazard and perspectives}

The March-April 2006 eruption illustrates that hornito collapses and rapid lava emplacement can put OL visitors at risk. Although the risk for local populations from larger effusive and explosive eruption remains limited, there is a need for multidisciplinary research, monitoring and further risk assessment. In the absence of ground-based monitoring, RS offers the possibility to detect ongoing events. Radar interferometry (InSAR) to monitor OL ground deformation has now been initiated [Study and Monitoring of African Active Volcanoes (SAMAAV) project, coordinated by F. Kervyn]. Preliminary results suggest deformation occurred on the upper flank directly before or during 2006 event.

Most information in the first news reports, disseminated internationally, was not accurate. To reduce risk, enhanced risk awareness, event preparedness and effective communication between relevant stakeholders (authorities, scientists, local people and media) are needed, together with enforcement of exclusion zones when appropriate. A way to discriminate between dust plumes from collapse events and ash plumes from explosive eruptions is also needed to avoid misreporting in the news media that may adversely affect tourism at OL.

Acknowledgements We thank all who contributed with observations, photographs or field assistance, including Dean Polley, Matt Jones, UDSM staff members, David Peterson, Celia Nyamweru, Daniela Szczepanski, Bernard Duycks, Thierry Sluys, Bernard Masson (LAVE Belgique), Chris Weber, Rohit Nandedkar and the TGS. We acknowledge field assistance by Majura Songho. MK and GGJE are supported by the Belgian NSF (FWO-Vlaanderen). MK thanks the "Fondation Belge de la Vocation" for funding his field expedition with FK. JK and JK are supported by DFG project Ke 136/ 40. HBM thanks The Royal Swedish Academy of Sciences and The Swedish Research Council for funding joint fieldwork with Jaana Hode Vuorinen at OL. Reviews by Dave Pyle and Harry Pinkerton helped improve the paper.

\section{References}

Carslaw HS, Jaeger JC (1959) Conduction of heat in solids. Oxford Univ Press, New York

Church AA, Jones AP (1994) Hollow natrocarbonatite lapilli from the 1992 eruption of Oldoinyo Lengai, Tanzania. J Geol Soc London 151:59-63 
Church AA, Jones AP (1995) Silicate-carbonate immiscibility at Oldoinyo-Lengai. J Petrol 36:869-889

Dawson JB (1998) Peralkaline nephelinite-natrocarbonatite relationships at Oldoinyo Lengai, Tanzania. J Petrol 39:2077-2094

Dawson JB, Pinkerton H, Norton GE, Pyle DM (1990) Physicochemical properties of alkali carbonatite lavas: data from the 1988 eruption of Oldoinyo Lengai, Tanzania. Geology 18:260-263

Dawson JB, Smith JV, Steele IM (1992) 1966 ash eruption of the carbonatite volcano Oldoinyo Lengai: mineralogy of lapilli and mixing of silicate and carbonate magmas. Mineral Mag 56:1-16

Dawson JB, Pinkerton H, Pyle DM, Nyamweru C (1994) June 1993 eruption of Oldoinyo Lengai, Tanzania: exceptionally viscous and large carbonatite lava flows and evidence for coexisting silicate and carbonate magmas. Geology 22:799-802

Dawson JB, Keller J, Nyamweru C (1995) Historic and recent eruptive activity of Oldoinyo Lengai. In: Bell K, Keller J (eds) Carbonatite volcanism: Oldoinyo Lengai and the petrogenesis of natrocarbonatites. Springer, Berlin, pp 4-22

Dawson JB, Pyle DM, Pinkerton H (1996) Evolution of natrocarbonatite from a wollastonite nephelinite parent: evidence from the June 1993 eruption of Oldoinyo Lengai, Tanzania. J Geol 104:41-54

GVN (1994) Oldoinyo Lengai: new active hornito and central depression. Bull Global Volc Network 19(09)

GVN (1999) Oldoinyo Lengai: lava flow spilling over the crater rim in November 1998. Bull Global Volc Network 24(02)

GVN (2002) Oldoinyo Lengai: lava exits crater at 3 points during January 2001-September 2002. Bull Global Volc Network 27(10)

GVN (2003) Oldoinyo Lengai: continuing lava flows and vent activity in late December 2002. Bull Global Volc Network 28(02)

GVN (2004) Oldoinyo Lengai: during February 2004, lavas still escape crater; temperature measurements. Bull Global Volc Network 29(02)

GVN (2005a) Oldoinyo Lengai: tall hornito almost reaches summit elevations; more lava spills over rim. Bull Global Volc Network 30(04)

GVN (2005b) Oldoinyo Lengai: lava continues to spill over crater rim through much of 2005. Bull Global Volc Network 30(10)

GVN (2006) Oldoinyo Lengai: unusual activity at summit crater during late March and early April 2006. Bull Global Volc Network 31(03)

GVN (2007) New lava linked to Plinian eruptions of AugustSeptember 2007. Bull Global Volc Network 32(11)

Huppert HE, Sparks RSJ (1985) Komatiites I: eruption and flow. J Petrol 26:694-725

Huppert HE, Sparks RSJ, Turner JS, Arndt NT (1984) Emplacement and cooling of komatiite lavas. Nature 309:19-22

Ihucha A (2006a) Villagers flee as volcano erupts. The Guardian, Arusha: 04-01-2006

Ihucha A (2006b) Keep off Oldoinyo Lengai, NCAA warns. The Guardian, Arusha: 04-15-2006

Jarvis RA (1995) On the cross-sectional geometry of thermal erosion channels formed by turbulent lava flows. J Geophys Res 100:10,127-10,140

Kafumu PD, Petro FN, Mulabwa D (2006) Report on the investigation of Oldoinyo Lengai volcanic eruption of 28-29 March 2006. The United Republic of Tanzania ministry of energy and minerals internal report, pp 31

Keller J, Krafft M (1990) Effusive natrocarbonatite activity of Oldoinyo Lengai, June 1988. Bull Volcanol 52:629-645
Keller J, Zaitsev AN (2006) Calciocarbonatite dykes at Oldoinyo Lengai: the fate of natrocarbonatite. Can Mineral 44:857-876

Kervyn M, Harris AJL, Belton F, Mbede E, Jacobs P, Ernst GGJ (2008) Thermal remote sensing of the low-intensity thermal anomalies of Oldoinyo Lengai, Tanzania. Int J Remote Sensing (in press)

Klaudius J, Keller J (2006) Peralkaline silicate lavas at Oldoinyo Lengai, Tanzania. Lithos 91:173-190

Mattsson HB, Hode Vuorinen J (2008) Emplacement, cooling and inflation of lava flows during the March-April 2006 eruption of Oldoinyo Lengai, Tanzania. Bull Volcanol (in press)

Mbede E (2006) Preliminary report on Oldoinyo Lengai March, 24 April, 5, 2006 volcanic eruption. Geology Dept Univ Dar es Salaam Internal Rep, pp 10

McKie D, Frankis EJ (1977) Nyerereite-New volcanic carbonate mineral from Oldoinyo-Lengai Tanzania. Zeitsch Kristallogr 145:73-95

Mvungi A (2006) Jitters as experts check volcanic action in Ngorongoro. The Guardian, Arusha 04-17-2006

Norton GE, Pinkerton H (1997) Rheological properties of natrocarbonatite lavas from Oldoinyo Lengai, Tanzania. Eur J Mineral 9:351-364

Oppenheimer C (1997) Satellite observation of active carbonatite volcanism at Oldoinyo Lengai, Tanzania. Int $\mathrm{J}$ Remote Sen 19:55-64

Peterson TD (1990) Petrology and genesis of natrocarbonatite. Contrib Mineral Petrol 105:143-155

Petibon CM, Kjarsgaard BA, Jenner GA, Jackson SE (1998) Phase relationships of a silicate-bearing natrocarbonatite from Oldoinyo Lengai at 20 and $100 \mathrm{MPa}$. J Petrol 39:2137-2151

Pinkerton H, Norton GE, Dawson JB, Pyle DM (1995) Field observations and measurements of the physical properties of Oldoinyo Lengai alkali carbonatite lavas, November 1988. In: Bell K, Keller J (eds) Carbonatite volcanism: Oldoinyo Lengai and the petrogenesis of natrocarbonatites. Springer, Berlin, pp 23-36

Pyle DM, Dawson JB, Ivanovitch M (1991) Short-live decay-series disequilibria in the natrocarbonatite lavas of Oldoinyo Lengai, Tanzania: Constraints on the timing of magma genesis. Earth Planet Sci Lett 105:378-396

Pyle DM, Pinkerton H, Norton GE, Dawson JB (1995) The dynamics of degassing at Oldoinyo Lengai. In: Bell K, Keller J (eds) Carbonatite volcanism: Oldoinyo Lengai and the petrogenesis of natrocarbonatites. Springer, Berlin, pp 37-46

Smithsonian Institution/USGS Weekly Report (2006a) New Activity/ Unrest: Oldoinyo Lengai, 29 March-4 April 2006. http://www. volcano.si.edu/reports/usgs/

Smithsonian Institution/USGS Weekly Report (2006b) New Activity/ Unrest: Oldoinyo Lengai, 5 April-11 April 2006. http://www. volcano.si.edu/reports/usgs/

Wilmoth RA, Walker GPL (1993) P-type and S-type pahoehoe: A study of vesicle distribution patterns in Hawaiian lava flows. J Volcanol Geotherm Res 55:129-142

Wright R, Flynn LP, Garbeil H, Harris AJL, Pilger E (2004) MODVOLC: Near-real time thermal monitoring of global volcanism. J Volcanol Geotherm Res 135:29-49

Zaitsev AN, Keller J (2006) Mineralogical and chemical transformation of Oldoinyo Lengai natrocarbonatites, Tanzania. Lithos 91:191-207 